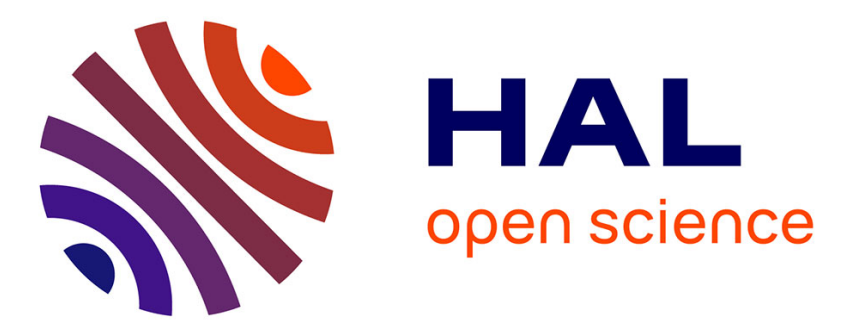

\title{
Micronutrient-efficient genotypes for crop yield and nutritional quality in sustainable agriculture. A review
}

Amir Hossein Khoshgoftarmanesh, Rainer Schulin, Rufus L. Chaney, Bahareh Daneshbakhsh, Majid Afyuni

\section{- To cite this version:}

Amir Hossein Khoshgoftarmanesh, Rainer Schulin, Rufus L. Chaney, Bahareh Daneshbakhsh, Majid Afyuni. Micronutrient-efficient genotypes for crop yield and nutritional quality in sustainable agriculture. A review. Agronomy for Sustainable Development, 2010, 30 (1), 10.1051/agro/2009017 . hal-00886520

\section{HAL Id: hal-00886520 \\ https://hal.science/hal-00886520}

Submitted on 1 Jan 2010

HAL is a multi-disciplinary open access archive for the deposit and dissemination of scientific research documents, whether they are published or not. The documents may come from teaching and research institutions in France or abroad, or from public or private research centers.
L'archive ouverte pluridisciplinaire HAL, est destinée au dépôt et à la diffusion de documents scientifiques de niveau recherche, publiés ou non, émanant des établissements d'enseignement et de recherche français ou étrangers, des laboratoires publics ou privés. 


\title{
Micronutrient-efficient genotypes for crop yield and nutritional quality in sustainable agriculture. A review
}

\author{
Amir Hossein Khoshgoftarmanesh ${ }^{1 *}$, Rainer Schulin ${ }^{2}$, Rufus L. CHANEY ${ }^{3}$, Bahareh DANESHBAKHSH ${ }^{1}$, \\ Majid AFYUNI ${ }^{1}$ \\ ${ }^{1}$ Department of Soil Science, Isfahan University of Technology, 84154, Isfahan, Iran \\ ${ }^{2}$ Institutes of Terrestrial Ecology, ETH Zurich, Universitaetstr. 16, 8092 Zurich, Switzerland \\ ${ }^{3}$ USDA-Agricultural Research Service, Environmental Management and Byproduct Utilization Laboratory, Building 007, BARC-West, \\ Beltsville, MD 20705, USA
}

(Accepted 29 April 2009)

\begin{abstract}
About 4 billion people will be added onto the present population by 2050. To meet further demand for food, agricultural production should increase on the existing land. Since the Green Revolution, higher crop production per unit area has resulted in greater depletion of soil phytoavailable micronutrients while less attention has been paid to micronutrients fertilization. Now, micronutrient deficiency has become a limiting factor for crop productivity in many agricultural lands worldwide. Furthermore, many food systems in developing countries can not provide sufficient micronutrient content to meet the demands of their citizens, especially low-income families. There are several solutions such as soil and foliar fertilization, crop systems, application of organic amendments to correct micronutrients deficiency and to increase their density in edible parts of plants. This review article presents (1) agronomic approaches to improve crop yield and micronutrient content of food crops, and (2) genotypic variation in uptake and accumulation of micronutrients. Considering ecological concerns, cultivation and breeding of micronutrient-efficient genotypes in combination with proper agronomic management practices appear as the most sustainable and costeffective solution for alleviating food-chain micronutrient deficiency. Micronutrient-efficient genotypes could provide a number of benefits such as reductions in the use of fertilizers, improvements in seedling vigor, and resistance to abiotic and abiotic stresses. Using bioavailable micronutrient-dense staple crop cultivars can also be used to improve the micronutrient nutritional status of human.
\end{abstract}

micronutrients / nutrient efficiency / biofortification / stress-tolerance indicators

\section{INTRODUCTION}

The world's population is estimated to increase from 6 billion to about 10 billion by 2050 . To meet the food demand of the growing world population, a large increase in food production is required. At the same time, the increases in world population will result in serious pressure on the existing agricultural land through urbanization and intensive cultivation (Alexandratos, 1995; Byrnes and Bumb, 1998). It has been estimated that to supply enough food for the world population in 2020, annual cereal production needs to increase by $40 \%$, from 1773 billion tons in 1993 to nearly 2500 billion tons in 2020 (Rosegrant et al., 1999, 2001). About $85 \%$ of the increase in total cereal demand will occur in the developing countries.

There are two strategies to increase food production: (a) to expand the agricultural area and (b) to enhance crop yields per unit area. The expansion of agricultural area is limited due to

* Corresponding author: amirhkhosh@cc.iut.ac.ir lack of suitable lands, urbanization, degradation of soils, and increasing water scarcity (Brown, 1997). To meet the further demand for food, agricultural production must increase on the existing land. This means that more crop food production must be achieved per unit of the presently available arable land.

Since the "Green Revolution", intensive cropping, cultivation of high-yield genotypes, improved agricultural mechanization, production of macronutrient fertilizers with low impurities of trace elements, and using modern irrigation systems has resulted in higher crop production per unit area and greater depletion of soil phytoavailable micronutrients.

Losses of micronutrients through erosion, leaching, liming of acid soils, decreased proportions of farmyard manure compared to chemical fertilizers, and use of marginal lands for crop production are other factors that have increased the incidence of micronutrient deficiencies in agricultural soil worldwide (Fageria et al., 2002). Micronutrient deficiency problems are also exacerbated by the high demand of modern crop 
cultivars. Accordingly, low levels of micronutrients have been reported on many crops grown in different countries (Cakmak et al., 1996; Fageria, 2000a; Galrão, 1999; Graham et al., 1992; Grewal and Graham, 1999; Martens and Lindsay, 1990). Therefore, micronutrient deficiency has become a limiting factor for crop productivity in many agricultural soils. In order to obtain the genetic potential yields of crops, correcting micronutrients deficiencies is necessary.

On the other hand, agricultural practices have almost always targeted higher crop yield production while minimizing costs. In addition, nutrient output of farming systems has never been a goal of either agriculture or of public policy. Thus, the increase in crop yield in many agricultural systems as a result of chemical fertilizer application has been accompanied with reduced micronutrients concentrations in the edible parts of different crops. So that, already, many food systems in developing countries can not provide sufficient micronutrients concentrations to meet the demands of their people especially lowincome families (ACC/SCN, 1992, 1997, 2000; Combs, et al., 1996; Combs and Welch, 1998; McIntyre et al., 2001; Welch et al. 1997; Welch, 1998).

Recently, mid 1980s, the nutrition community reported the global significance of micronutrient malnutrition (Allen, 2000). In 2001, fighting micronutrient malnutrition was considered an integral component of three of the eight Millennium Development Goals (MDGs) of the General Assembly of the UN to alleviate the world's greatest health and poverty issues by 2015 (United Nations General Assembly, 2000). The focus of improving the micronutrient quality of crops notes the density of bioavailable micronutrients in crops as consumed in order to take into account crop factors which increase or decrease the bioavailability of crop micronutrients (see below). For example, phytate in grains is well known to inhibit absorption or utilization of crop $\mathrm{Zn}$ by humans and livestock, such that grain phytate must be considered whenever the quality of grain $\mathrm{Zn}$ for human use is considered.

Deficiencies of iron, zinc, vitamin A, and iodine not only compromise the immune system, but can irreversibly retard development in infancy. Deficiency of any of these in a pregnant or lactating woman can result in subclinical mental retardation in children. Such children may be less fit to control their environment and to provide for their own food security in later life, to compete for better education and for higher level jobs within their society. Vitamin A deficiency can lead to poor night vision, eye lesions and, in severe cases, permanent blindness; increased illness and death from infections. Iodine deficiency can cause goiter, mental retardation, brain damage and reproductive failure. Iron deficiency can cause nutritional anemia, problem pregnancies, stunted growth, and lower resistance to infections, long-term impairment in mental function, decreased productivity, and impaired neural development. Zinc deficiency can cause growth retardation, delayed skeletal and sexual maturity, dermatitis, diarrhoea, alopecia, and defects in immune function with resulting increase in susceptibility to infection.

Several approaches such as soil and foliar fertilization, improved crop systems, application of soil amendments and organic nutrient sources are possible to correct micronutrients deficiency and to increase their density in edible parts of plants. Considering ecological concerns, sustainable agriculture is looking for more environmental-friendly and cost effective approaches with low input of energy and chemicals. Among different strategies applied for correcting micronutrient deficiency in the food chain from plant to human, the most sustainable solution, particularly for developing countries, seems to be cultivation and breeding of micronutrientefficient genotypes in combination with proper agronomic management practices.

Nutrient efficiency and nutrient-efficient genotypes have been defined in different ways (Stewart et al., 2005; Fageria et al., 2008). Definitions of nutrient efficiency generally can be divided into those emphasizing crop productivity and those emphasizing the internal plant nutrient requirement (Gourley et al., 1994). With regard to yield parameters, nutrient efficiency has been defined as the ability to produce a high plant yield in a soil that would otherwise limit the production of a standard genotype (Marschner, 1995). Other definitions of nutrient efficiency also referred to as 'agronomic efficiency', include the amount of shoot production per unit of nutrient applied (Caradus, 1990; Sauerbeck and Helal, 1990). Nutrient efficiency has also defined as yield response per unit of added nutrient or of nutrient in the crop shoots (Baligar et al., 1990; Blair, 1993; Thung, 1988). This paper will briefly discuss some aspects of using and developing micronutrient-efficient crop plant genotypes as a sustainable and cost-effective method for alleviating food-chain micronutrient deficiency malnutrition of humans.

\section{IMPROVING CROP YIELD}

Mineral nutrients have played an important role in enhancing crop production since the beginning of the green revolution. According to Borlaug and Dowswell (1993), nearly half of the increase in crop yields during the 20th century was due to chemical fertilizer application. Generally, improving the nutritional status of plants by applying fertilizers and maintaining soil fertility has been the critical step in doubling food production both in developed and developing countries (Loneragan, 1997). The increase in crop production has been mainly resulted from the application of N-P-K fertilizers (Brady and Weil, 2002). Since 1950, application of N-P-K fertilizers has been rapidly increased in agricultural lands while less attention has been paid to micronutrients fertilization. Further, higher crop production per unit area depleted greater amount of micronutrients from soils. Now, micronutrient deficiency is a limiting factor for attaining greater crop yields in many cultivated soils.

Accordingly, micronutrient deficiency has been reported widely in plant crops grown in different countries. For example, Fe deficiency in crops have been reported for various regions of Europe, east India, Bangladesh, Malta, Turkey, Zambia, and Mexico (Sillanpaa, 1982), Indonesia (Katyal and Vlek, 1985; Welch et al., 1991), several North, Central and South American countries (Leon et al., 1985), Australia, 
and most Mediterranean and west African countries (Donald and Prescott, 1975).

Zinc-deficient soils are widespread in Mediterranean countries (Cakmak et al., 1997b; Khoshgoftarmanesh et al., 2004a), Australia (Donald and Prescott, 1975; Sillanpaa and Vlek, 1985), China (Takkar and Walker, 1993), Africa (Cottenie et al., 1981), Asia (Katyal and Vlek, 1985; Welch et al., 1991), and North and South America (Fageria, 2000b; Lopes and Cox, 1977). Some crops (maize, rice) are especially susceptible to $\mathrm{Zn}$ deficiency in most countries where they are grown.

Manganese deficiency has also been reported in soils of the United States (Reuter et al., 1988), Central and South America (Leon et al., 1985), Europe (Welch et al., 1991), semiarid regions of China, India, southeast and western Australia, and many African countries (Welch et al., 1991).

The importance of certain trace elements for optimum growth and development of plants has been reported for the last century (Barker and Pilbeam, 2007; Cakmak, 2002; Marschner, 1995). Up to now, several trace elements (B, Br, $\mathrm{Cl}, \mathrm{Co}, \mathrm{Cu}, \mathrm{F}, \mathrm{Fe}, \mathrm{I}, \mathrm{Mn}, \mathrm{Mo}, \mathrm{Ni}, \mathrm{Na}, \mathrm{Rb}, \mathrm{Si}, \mathrm{V}$, and $\mathrm{Zn}$ ) are known to be essential for certain plants. Several nutrients have been shown necessary only for a few species (Al, I, Na, Si, $\mathrm{Rb}, \mathrm{Ti}, \mathrm{V}, \mathrm{F}, \mathrm{Br}$ ), and others are known to have stimulating effects on plant growth, although their functions are not yet recognized (Barker and Pilbeam, 2007). The essential micronutrients are those that their specific biochemical roles cannot be substituted by other elements. In the absence of adequate amounts of these elements inside plant tissues, crop growth and metabolic cycles will be impaired.

Several studies have reported the significant reduction in growth and yield of different plant species in soils deficient in $\mathrm{Fe}, \mathrm{Mn}, \mathrm{Zn}, \mathrm{Cu}, \mathrm{B}$, and other micronutrients (Cakmak et al., 1998; Kalayci et al., 1999; Khoshgoftarmanesh et al., 2004a, b, 2006a, b, 2007; Khoshgoftar and Hajimozaffari, 2006). Therefore, correcting micronutrient deficiency through appropriate approaches is necessary to achieve higher crop yields.

\section{CROP QUALITY AND HUMAN HEALTH}

The increase in food production to prevent starvation and malnutrition was the main goal driving the agricultural "Green Revolution" during the latter half of the 20th century (Welch and Graham, 1999). In parallel to increase in crop yield in many agricultural systems as a result of chemical fertilizer application and improved agronomic practices, micronutrients contents in the edible parts of different crops were reduced to levels lower than that of the traditional crops. Thus, many food systems in developing countries can not provide sufficient micronutrient contents to meet the demands of their people especially low-income families (ACC/SCN, 1992, 1997, 2000; Combs et al., 1996; Combs and Welch, 1998; McIntyre et al., 2001; Welch et al., 1997; Welch, 1998). Humans need trace elements in sufficient levels to sustain life. There are also some dietary substances such as phytate that affect nutrients bioavailability and as a result, human nutritional status (ACC/SCN, 1992, 1997, 2000; Combs et al., 1996; Combs and Welch, 1998; McGuire, 1993; Welch et al., 1997; Welch, 1998).

Micronutrient malnutrition or hidden hunger now affects more than $40 \%$ of the world's population (United Nations Administrative Committee on Coordination-Subcommittee on Nutrition, 1992). The consequences of micronutrient deficiencies are mostly found among women, infants and children from poor families in developing countries (Buyckx, 1993; Ramalingaswami, 1995; World Health Organization, 1992; Mason and Garcia, 1993). However, micronutrient malnutrition is not restricted to developing countries and is also widespread in well-developed industrialized countries (Cobiac and Baghurst, 1993; US Department of Health and Human Services, 1990).

There has been a huge increase in the number of people suffering from micronutrient malnutrition over the last four decades. For example, Fe deficiency anemia has grown from about $30 \%$ of the world's population in the 1960 s to over $40 \%$ during the late 1990s. It has been estimated that over 3.7 and 1 billion people are at the risk of iron and iodine deficiency disorders, respectively. In addition, Zn, Se, vitamin A, vitamin $\mathrm{C}$, vitamin $\mathrm{D}$ and folic acid deficiencies are widespread among populations especially in developing countries (Combs et al., 1996; World Health Organization, 1999). Many zinc nutrition specialists believe that zinc is as important as iron deficiency (Gibson, 1994; Gibson et al., 2008). Copper, boron, manganese, chromium and lithium are other micronutrients that are needed for nutrient balance.

\subsection{Consequences of micronutrient deficiencies}

Impaired immune function, increased mortality and morbidity rates, lower worker productivity, diminished intellectual performance, lower educational attainment, a lower livelihood, higher birth rates, lower standard of living performance, and increased rates of chronic diseases including coronary heart disease, cancer and diabetes are some consequences of micronutrient hidden hunger (Pinstrup-Andersen, 1999; Sanghvi, 1996; Welch and Graham, 2000).

Micronutrients malnutrition increase human susceptibility to infections and is the most important risk factor for the disease in developing countries (Brabin and Coulter, 2003; Food and Agriculture Organization of the United Nations, 2004; Murray and Lopez, 1997; Black, 2003). Anemia, problem pregnancies, stunted growth, lower resistance to infections, long term impairment in mental function, decreased productivity and impaired neural development are some consequences of iron deficiency. Zinc deficiency may result in growth retardation, delayed skeletal and sexual maturity, dermatitis, diarrhea, alopecia and defects in immune function with resulting increase in susceptibility to infection (Pinstrup-Andersen, 1999; Welch and Graham, 2000).

\subsection{Nutrient bioavailability}

The nutritional quality of a diet can be determined based on the concentration of individual nutrients as well as interactions 
of other elements, promoters and antinutrients which affect bioavailability of micronutrients. In fact, the degree to which a nutrient is absorbed from the diet depends on antinutrients contents e.g., phytate, tannins and antivitamins (Graham et al., 2000). High levels of antinutrients including phytate and tannins in the diet reduce the bioavailability of micronutrients including $\mathrm{Fe}$ and $\mathrm{Zn}$, while promoters such as vitamin $\mathrm{A}$ or $\beta$-carotene and vitamin $C$ enhance micronutrients bioavailability in humans (Garcia-Casal et al., 1998). Phytate is an important antinutrient to zinc absorption. Phytate is especially high in cereal grains. Depending on the plant genotype, about 70 to $90 \%$ of the total phosphorus in whole grain is in the form of phytate (O'Dell et al., 1972). Other antinutrients are of lesser importance in cereals.

Another factor affecting the bioavailability of micronutrients is interaction with other nutrients. For example, interactions between vitamin A (retinol) and zinc has been found in the late 20th century (Christian and West, 1998; Solomons and Russell, 1980). Synergistic and antagonistic interactions among chemically similar metal cations have been characterized in both plants and animals (Hill and Matrone, 1970). Such a synergistic effect strongly indicates that breeding for staples that are dense in both iron and zinc is required in order to effectively address iron-deficiency anemia. It has been reported that the anemia could be corrected using vitamin A but not iron supplementation (Hodges et al., 1978).

Cereal-based foods with low concentrations and reduced bioavailability of micronutrients have been considered a major reason for the widespread deficiencies of $\mathrm{Zn}$ and $\mathrm{Fe}$ in developing countries (Graham et al., 2001; Welch and Graham, 1999). Thus it is essential to find sustainable approaches to produce food supplies adequate in quantity and proper nutritional quality.

\section{CORRECTION OF MICRONUTRIENT DEFICIENCY}

\subsection{Fertilizer application}

Alleviation of micronutrient deficiencies to improve crop yields is difficult due to large temporal and spatial variation in phytoavailability of soil micronutrients (Brennan and Bolland 2006; Shaver et al., 2007). The easiest and most straightforward practice to correct micronutrient deficiency is to apply micronutrient fertilizers. Soil application of fertilizer is economically more affordable. However, in soils with high $\mathrm{pH}$, most of soil-applied micronutrients will become unavailable for plant uptake within a few years (Martens and Westermann, 1991). The loss in residual effect of soil-applied nutrient requires adding more fertilizer to maintain a sufficient level of phytoavailable element, although total soil element contents are still high and actually increasing from application to application. Increased total soil metal may create problems of micronutrients losses or toxicity in the future, especially under conditions that mobilize soil metal such as soil acidification. Furthermore, soil application of fertilizers is not always a useful approach to increase micronutrients concentrations in cereal grain. Many studies reported minimal or no increases in grain micronutrient content, with increasing soil application of micronutrient fertilizers even when yield was increased.

Applied soluble micronutrients fertilizers become ineffective rather rapidly as the dissolved metals react with soil minerals and organic matter. In comparison with inorganic fertilizers, synthetic and natural chelates have the advantage of keeping the applied nutrient in solution in a less reactive form. Chelates are particularly appropriate for applications of $\mathrm{Zn}$ and $\mathrm{Fe}$ to alkaline and calcareous soils. Soil application of inorganic Fe fertilizers to Fe-deficient soils is usually ineffective because of rapid conversion of soluble Fe into plantunavailable solid $\mathrm{Fe}$ (III) forms. In contrast, an application of synthetic Fe-chelates for correction of Fe deficiency is effective (Wallace and Wallace, 1982) for a longer period, or actually long enough to support one crop of tree fruits which are commonly fertilized with Fe-chelates.

The effectiveness of various synthetic and natural chelates has been widely investigated (Alvarez and Gonzalez, 2006; Gonzalez et al., 2007; Prasad and Sinha, 1981). Despite their effectiveness, application of chelates is generally expensive (Wallace and Wallace, 1982), and is likely to be even more uneconomic if the aim is to increase micronutrient concentration in the grain rather than to increase yield. In addition, application of metal chelates may result in potential leaching risk because the more mobile the chelate, or the less biodegradable the carrier, the greater the risk for leaching (Gonzalez et al., 2007).

Foliar application can provide a rapid correction of severe deficiencies commonly found during the early stages of growth, and are temporary solutions to the problem. Foliar fertilization is more effective than soil application, but too expensive for resource-poor farmers. Low penetration rates in thick leaves, run-off from hydrophobic surfaces, wash off by rainfall, rapid drying of spray solution, limited translocation within the plant, and leaf damage are other problems related to foliar applications (Marschner, 1995). Most foliar-applied micronutrients are not efficiently transported toward roots, which may remain deficient. Therefore, application of micronutrients to either soil or foliage may be successful in increasing grain yield only in well-defined circumstances.

Another method to apply micronutrients to crop plants is the treatment of seeds with fertilizers, a technique called "seed priming". The most effective way to prime micronutrients in seeds is to grow the parent crop on a soil with high levels of phytoavailable $\mathrm{Mn}$ or $\mathrm{Zn}$, while spraying high levels of $\mathrm{Zn}$ and $\mathrm{Mn}$ fertilizers on the plants during seed filling can also increase seed levels considerably. Mixing micronutrients with seeds must be limited to levels which do not harm the germinating seeds. It has been reported that seed priming with $\mathrm{Zn}$ sulphate resulted in a stronger increase in the grain yield of wheat grown on $\mathrm{Zn}$-deficient soil than foliar $\mathrm{Zn}$ application after germination, but it did not significantly increase grain $\mathrm{Zn}$ concentration in contrast to foliar and soil application (Rengel and Graham, 1995; Yilmaz et al., 1997, 1998). 'On-farm' seed priming with water is an effective way to increase yield in maize and is important for resource-poor farmers as it is a low- or zero-cost technology and requires few external inputs 
(Harris et al., 2007). Recently, Harris et al. (2008) reported that priming seeds with $\mathrm{ZnSO}_{4}$ significantly increased the grain $\mathrm{Zn}$ concentration and concluded that using $\mathrm{ZnSO}_{4}$ to prime seeds was very cost-effective, with net benefit-to-cost ratios of 75 for wheat and 780 for chickpea.

Correction of micronutrients deficiency via fertilization, especially in calcareous soils, is not always successful and sustainable due to agronomic and economic factors such as reduced availability of micronutrient element due to topsoil drying, subsoil constraints, disease interactions, and cost of fertilizer in developing countries (Graham and Rengel, 1993).

Some chemical fertilizers, especially $\mathrm{Zn}$ and Fe fertilizer manufactured from industrial byproducts or mine wastes contain various contaminants such as cadmium and $\mathrm{Pb}$ (Afyuni et al., 2007). The potential risks to environmental quality posed by their repeated application to soil require careful evaluation (Mortvedt, 1985, 1996) especially for rice production (Chaney et al., 2004). Recently, preserving the environment is becoming a more important objective of agriculture to achieve sustainable agricultural goals (Cakmak, 2002; Tillman, 1999). To avoid potential future environmental risks, a more sustainable strategy is required than just adding chemical micronutrients fertilizers to the soil. Total amounts of some micronutrients such as $\mathrm{Zn}$ and $\mathrm{Fe}$ in agricultural soils are generally orders of magnitude higher than the crop demand. Thus, micronutrients deficiency in crops is a problem of insufficient phytoavailability in almost all cases and not of absolute lacking sufficient quantity of micronutrients.

\subsection{Soil amendments}

Soil amendments are frequently used by farmers to improve some physical and chemical properties of soils (e.g. adjusting soil $\mathrm{pH}$ ) in order to enhance plant growth. Limestone application is an effective and common practice to improve crop productivity of acidic soils (Foy, 1984, 1992; Kochian, 1995). Adding limestone may depress the uptake of $\mathrm{Zn}, \mathrm{Cu}, \mathrm{Fe}$, and $\mathrm{Co}$, and increase the uptake of Se and Mo by plants (Foy, 1984). The pH largely controls micronutrients solubility in soil and a small change in $\mathrm{pH}$ significantly affects solubility and uptake of metals such as $\mathrm{Zn}, \mathrm{Cu}, \mathrm{Mn}$, and $\mathrm{Fe}$. Considering increased $\mathrm{pH}$ of acidic soils by liming, micronutrient deficiencies become more severe after liming (Verma and Minhas, 1987). A high soil-pH favors the oxidation of reduced forms of $\mathrm{Se}$ such as $\mathrm{Se}^{-2}$ and $\mathrm{SeO}_{3}^{-2}$ to the more soluble and plantavailable $\mathrm{SeO}_{4}^{-2}$ anion.

Several studies have examined the effects of combined fertilization with lime and P. Phosphorus causes changes in the extractability of $\mathrm{Zn}$ and, in almost all soils, further aggravates $\mathrm{Zn}$ deficiency in susceptible crops causing decreases in grain $\mathrm{Zn}$ concentration (Hylander, 1995). Thus, $\mathrm{Zn}$ fertilizers must often be applied to ameliorate Zn deficiency associated with limestone application (Tagwira, 1993).

In contrast to limestone, gypsum $\left(\mathrm{CaSO}_{4}\right)$ and elemental $\mathrm{S}$ are used to decrease the $\mathrm{pH}$ of alkaline soils as well as to amend sodic and saline-sodic soils. Application of acidproducing amendments on alkaline and calcareous soils could decrease soil $\mathrm{pH}$ and consequently increase plant-available $\mathrm{Fe}$, $\mathrm{Mn}, \mathrm{Zn}, \mathrm{Cu}$, and $\mathrm{Co}$. Gypsum is used to exchange $\mathrm{Ca}$ for $\mathrm{Na}$ on the soil cation-exchange complex and to remove bicarbonate from the soil solution. Removal of bicarbonate from the soil solution can be highly beneficial for lowering the soil $\mathrm{pH}$ and increasing the availability of micronutrients (Singh et al., 1989). Singh et al. (1989) reported that gypsum application in a sodic soil increased the mean concentration of $\mathrm{Mn}, \mathrm{Zn}$ and $\mathrm{Cu}$ in mesquite (Prosopis julitlora). Application of gypsum caused significant reductions in $\mathrm{pH}$ and electrical conductivity (Singh et al., 1989). The increase in soil availability of micronutrient as a result of gypsum application might be attributed to the decrease in soil $\mathrm{pH}$ and improved soil physical properties. Further research is necessary to ascertain whether benefits of applying gypsum to alkali, sodic soils are significant in terms of increasing micronutrient density in grain.

\subsection{Organic fertilizer sources}

Application of different organic materials e.g. manures, plant residues and waste materials is a recommended strategy to improve soil fertility and enhance nutrient use efficiency. Organic sources application is known as an effective management strategy to sustain high crop productivity in many cropping systems. Using organic sources may affect crop micronutrient nutrition through affecting soil physical and chemical properties, producing better root growth environment and adding some micronutrients to soil (Rengel et al., 1999).

Soil organic matter has a variety of direct and indirect influences on the phytoavailability of micronutrients in soil and their uptake by plants (Rengel et al., 1999). Binding of some metals such as $\mathrm{Zn}$ to organic matter reduces the concentration of free cation in solution, but if the metal-organic complexes are dissolved, then the increase in total dissolved ion may actually also increase effective metal phytoavailability at the root-rhizosphere interface, depending on the mobility and the dissociation kinetics of the metal-DOC complexes. Chelation of $\mathrm{Zn}$ and $\mathrm{Fe}$ by organic matter holds these nutrients in forms more accessible by roots within the rhizosphere, and retards formation of insoluble solid forms such as oxides and carbonates in soil (Schulin et al., 2009).

Adding organic resources such as crop residues, green manure, livestock manure, municipal biosolids or their composts or co-composts to soil has a number of beneficial effects on micronutrient nutrition including additional supply of some nutrients with the added organic matter, increase in ion exchange capacity and thus of the fractions of easily available nutrients, improved soil structure, increase in water storage capacity, improved drainage and aeration, increased accessibility of soil for plant roots, decreased salinity, stimulation of microbial exudation of organic ligands and of other microbial activities and as a result, accelerated release of nutrients from secondary soil matter, enhanced nutrient supply through mycorrhizae, and protection against root pathogens. All these effects promote plant growth, the development of the root system and thus also its capacity to acquire micronutrients (Schulin et al., 2009). 
The formation of metal complexes with organic ligands in the soil solution is generally found to increase the mobility of soil micronutrients. On the other hand chelation can substantially reduce cellular metal uptake. Because microelements bound to the soil surfaces can only reach roots by diffusion, the mobilization effect of chelation generally seems to cause greater increase in plant uptake. In previous studies even strong chelates (Zn-EDDS, Zn-EDTA) still resulted in a net increase of Zn uptake (Novack et al., 2008). This can be explained by increased rate of movement of the microelement from soil surfaces to root uptake surfaces by movement of dissolved chelated elements (e.g., Wallace and Meuller, 1973). It has also to be considered that leaf-applied chelates might not be helpful for transport of micronutrients into grain (Cakmak, 2008; Novack et al., 2008).

Effects of different organic amendments on correcting micronutrients deficiencies have been widely investigated; however, very few controlled experiments have been done to determine which types of organic matter practices significantly enhance or depress the levels of micronutrients in edible portions of major food crops. Therefore, more research is needed to understand the impact of various types of organic amendments on crop nutritional quality.

\subsection{Plant residue}

In many countries, especially arid and semi-arid regions, very little or no crop residue is left in the field; much is used for feeding animals or for fuel (Timsina and Connor, 2001). It is estimated that more than 1000 million tons of cereal residues are being annually produced in the developing countries (FAO, 1999). Rice, wheat, corn, soybean, barley, rapeseed, and potato are the major residue-producing crops that globally produced 2956 million tons of residues in 1998 (FAO, 1999).

Crop residues are considered as important sources of several micronutrients. Rice and wheat remove 96, 777, 745, 42, 55, and $4 \mathrm{gha}^{-1}$ of $\mathrm{Zn}, \mathrm{Fe}, \mathrm{Mn}, \mathrm{Cu}, \mathrm{B}$, and Mo per ton, respectively. By estimating the total crop residue production of 105 million tons in India, and based on micronutrient contents of the residues, the micronutrient potential associated with crop residues would be about 35400 tons (Prasad, 1999). About 50 to $80 \%$ of $\mathrm{Zn}, \mathrm{Cu}$, and $\mathrm{Mn}$ taken up by rice and wheat crops can be recycled through residue incorporation (Prasad and Sinha, 1995b). Therefore, recycling of crop residues can help improve soil availability of micronutrients.

Crop residues addition to flooded soils stimulates microbial metabolism and thus increases soil solution $\mathrm{Fe}$ and $\mathrm{Mn}$ concentrations due to greater redox potential change (Katyal, 1977; Yodkeaw and De Datta, 1989; Atta et al., 1996). In calcareous soils, organic acids produced during crop residue decomposition may increase plant $\mathrm{Zn}$ uptake by dissolving $\mathrm{Zn}$ from the solid-phase pool to soil solution (Prasad and Sinha, 1995a). Chelating agents released from decomposing crop residues increase the concentration of total diffusible $\mathrm{Zn}$ and its diffusion coefficient (Singh et al., 2005). Rice straw application has been found to increase the $\mathrm{Zn}$ content of rice plants, possibly through its amelioration of soil $\mathrm{pH}$ and exchangeable sodium percentage (Singh et al., 2005). In contrast, crop residue application has been reported to decrease the labile $\mathrm{Zn}$ pools in an alkaline soil (Kang, 1988). Other researchers (Raj and Gupta, 1986) have also reported that application of rice or wheat straw decreased the phytoavailable $\mathrm{Zn}$ concentration in both flooded and upland soils.

Crop residues may also negatively affect crop production in the short term because of $\mathrm{N}$ immobilization and phytotoxic compounds release in allelopathic interactions. Plants may release chemical compounds which can either stimulate or inhibit the growth and development of another plant. These compounds are dispersed into the environment from root exudates, leaf leachates, or from dead and decaying plant parts (Rose et al., 1984; Huber and Abney, 1986). Nutrient uptake may be reduced by allelochemicals (Bhowmik and Doll, 1984; Rice, 1984; Barnes and Putnam, 1986). It has been suggested that sweet potato residues have an allelopathic effect (Walker and Jenkins, 1986). Sweet potato and cowpea indicator plants grown in sweet potato crop residues displayed symptoms resembling complex nutrient deficiencies. Abiotic factors, such as reduced soil $\mathrm{pH}$, increased soil osmotic potential, reduced oxygen concentrations and low nutrient content of the residue, may also have caused growth inhibition and as a result, reduced plant nutrient uptake. Walker et al. (1989) reported that plant uptake of $\mathrm{P}, \mathrm{K}, \mathrm{Ca}, \mathrm{Mg}, \mathrm{S}, \mathrm{Zn}, \mathrm{B}$ and $\mathrm{Cu}$ were substantially lower in plants grown in soil with amendment by sweet potato root or vine residues than in plants grown in without sweet potato residue treatments. Successful integration of crop residue management strategies into cropping systems requires understanding of how crop residues influence cycling of nutrients from soil and fertilizers, as well as their effects on soil chemical, physical and biological properties, and crop production.

\subsection{Animal manure}

Livestock manure is a good source of plant nutrients and its application in agricultural lands is a traditional nutrient management in many countries worldwide. The use of manures can also change plant-available micronutrients by adding micronutrients or by changing both the physical and biological characteristics of the soil (Stevenson, 1991, 1994). Eghball et al. (2004) found that applications of manure and compost not only improved soil physical properties but also provided nutrients for growing corn. The residual effects of manure on soil properties remained several years after application. Gao et al. (2000) found that manure was a better source of available $\mathrm{Fe}, \mathrm{Mn}$, and $\mathrm{Zn}$ compared to synthetic fertilizers, but manure accelerated the depletion of available $\mathrm{Cu}$. Manure not only supplies large amounts of $\mathrm{Zn}$ to the soil, but also promotes biological and chemical reactions that result in the dissolution of non-available Zn (Wei et al., 2006). Wei et al. (2006) reported that manure application had no significant effect on available $\mathrm{Cu}$. This might be attributed to the low amount of $\mathrm{Cu}$ in the manure used in this experiment. Copper could be bound to organic matter and thus be relatively unavailable to plants. 
Zinc and $\mathrm{Cu}$ may be added to poultry feeds as a preventive for scour and to suppress bacterial action in the gut. Accordingly, $\mathrm{Zn}$ and $\mathrm{Cu}$ concentrations of some compound poultry and swine feeds are several times higher than that required by the animals for healthy development. In areas where animal manures have been applied for many years and where applications are expected to continue, high amounts of heavy metals (particularly $\mathrm{Zn}$ and $\mathrm{Cu}$ ) may accumulate in soil (Nicholson et al., 1999). The micronutrient contents of farm manures largely depend on their concentrations in the feeds consumed and the efficiency of feed conversion by the animals. Fleming and Mordenti (1991) reported mean Zn concentrations of cattle manures in Belgium of $580 \mathrm{mg} \mathrm{kg}^{-1} \mathrm{DM}$. In Switzerland, cattle manures generally contain $<200 \mathrm{mg}$ Zn/kg DM (Menzi and Kessler, 1998). Webber and Webber (1983) reported cattle manure $\mathrm{Zn}$ concentrations in the range of $30 \pm 225 \mathrm{mg} \mathrm{kg}^{-1} \mathrm{DM}$. The mean $\mathrm{Cu}$ concentration in cattle manures was reported to be $16 \pm 62 \mathrm{mg} \mathrm{kg}^{-1} \mathrm{DM}$ (Fleming and Mordenti, 1991; Menzi and Kessler, 1998). Sims and Wolf (1994) reported $\mathrm{Zn}$ concentrations ranging from nondetectable to $660 \mathrm{mg} \mathrm{kg}^{-1} \mathrm{DM}$ in poultry manure and from non-detectable to $669 \mathrm{mg} \mathrm{kg}^{-1} \mathrm{DM}$ in poultry litter. The maximum content of $\mathrm{Cu}$ in poultry manures and litters were $232 \mathrm{mg} \mathrm{kg}^{-1} \mathrm{DM}$ and $1003 \mathrm{mg} \mathrm{kg}^{-1} \mathrm{DM}$, respectively.

Farm manures are a valuable source of major plant nutrients $(\mathrm{N}, \mathrm{P}, \mathrm{K})$ and organic matter. However, care must be taken to ensure that manure applications containing elevated levels of heavy metals do not cause long-term soil contamination. Then, the typical amounts of heavy metals in solid manures have to be calculated before manure addition to soil. Excessive cumulative application of manure can cause accumulation of phosphate in surface soils, which increases the potential for runoff of phosphate which can cause adverse effects in streams. Thus applications of manures are being limited to the phosphate fertilizer requirement of crops rather than the $\mathrm{N}$ fertilizer requirement which applied much higher annual manure amounts. Several groups have developed models for application of major and micronutrients with all soil amendments for large areas, considering livestock manure, biosolids, phosphate and other fertilizers. These studies illustrate accumulation of $\mathrm{Zn}, \mathrm{Cu}$ and $\mathrm{Cd}$ in soils when microelement rich manures are applied (Keller and Schulin, 2003). These issues are more important in areas with intensive animal production because feedstuffs are imported from distant farms, but the livestock residues are applied to the local farm of the livestock producer. In developing countries where livestock production is achieved with local inputs, accumulation of $\mathrm{Zn}$ and other elements in the soil is less of a concern.

\subsection{Organic amendments}

Biosolids and composts are usually effective $\mathrm{Zn}$ and $\mathrm{Cu}$ fertilizers. Possibility of correcting micronutrient deficiency in different plant species by application of biosolids, municipal waste leachates, and compost has been reported (Khoshgoftarmanesh and Kalbasi, 2002). When soils need Zn or $\mathrm{Cu}$ fertilization, high quality biosolids and composts could be used to supply the required $\mathrm{Zn}$ and $\mathrm{Cu}$. Such amendments are not normally able to replace $\mathrm{B}$ fertilizers, but mixing with coal combustion byproducts can supply adequate B for the mixture to serve as B fertilizer (Chaney and Ryan, 1993).

Because production of composts will save costs in both urban and agricultural areas, they can be used as inexpensive fertilizers. Although such benefits are possible from use of composts, these products must be safe for sustainable use in horticulture and agriculture for their use to be permitted by governments, and must reliably supply nutrient and organic matter benefits to become competitive products in the market place. The potential presence of pathogens, heavy metals, xenobiotic compounds, and possible element imbalance in composts has caused concern to compost application. Some believe that because the concentration of $\mathrm{Zn}$ or $\mathrm{Cu}$ in composts is higher than found in background soils, these materials must not be utilized on soils. However, researchers have used high quality organic matter/compost products for decades without adverse effects (Andersson, 1983; Chaney and Ryan, 1993; Woodbury, 1992). Composts prepared in developing countries often do not receive the contaminants which have caused concerns in developed countries. Over time boron use in glues and other products has declined such that municipal solid wastes which used to commonly contain phytotoxic levels of boron are only a useful B fertilizer today. As with biosolids, composts from off-farm sources should be analyzed for contaminants and nutrients so that these resources can be wisely managed on cropland.

\subsection{Crop rotation}

Cropping systems practices influence micronutrient availability. A preceding crop may influence soil conditions that govern soil fertility in general and micronutrients phytoavailability to the successive crop in particular. These can result from residual effects of root litter and exudates on soil physical and chemical parameters as well as on soil microorganisms, generation of root channels, and other plant-soil interactions. Legumes may positively affect soil quality by improving soil physical properties. Improved physical properties of the soil provide a better root growth condition and as a result, enhance uptake of immobile micronutrients by roots. Crop rotation systems may also affect some soil chemical properties (i.e. pH). Alvey et al. (2001) found that a legume rotation system was more effective in increasing the $\mathrm{pH}$ of the rhizosphere as compared to continuous sorghum cropping system. The increase in $\mathrm{pH}$ was considered as an important mechanism of the plant to cope with acidity-induced nutrient deficiency. However, in the long term, $\mathrm{N}$ fixation increases soil acidity and must be counteracted by alkaline amendments. Khoshgoftarmanesh and Chaney (2007) reported that wheat plants grown after sunflower accumulated more $\mathrm{Zn}$ in their grains as compared to those planted after cotton. Liu et al. (2002) found that a rice-upland crop rotation promoted the reduction of $\mathrm{Mn}$ in the surface soil and accelerated the oxidation and accumulation of $\mathrm{Mn}$ in the subsoil. Bronick and Lal (2005) reported that crop rotation enhanced 
soil organic carbon accumulation. Diekow et al. (2005) reported that higher residue input associated with legume-based cropping systems significantly increased soil organic carbon. Mitchell and Entry (1998) found that long-term planting of legumes as a winter cover crop resulted in higher soil organic carbon levels compared with treatments that did not include a winter cover crop.

Wei et al. (2006) found that available $\mathrm{Zn}$ and $\mathrm{Cu}$ varied with different cropping systems. The amount of phytoavailable $\mathrm{Cu}$ in soil decreased in the order: continuous clover $>$ crop-legume rotation $>$ continuous wheat. Differences among cropping systems could probably be attributed to differences in the $\mathrm{Cu}$ uptake capacity of each crop. Long-term cultivation of leguminous crops may lead to a large increase in available $\mathrm{Mn}$ due to changes in the soil microenvironment by leguminous crops that result in the release of plant available Mn (Williams C.H. and David, 1976).

Gunes et al. (2007) found that intercropping of wheat and chickpea inoculated with a Rhizobium on a calcareous clay loam soil $(\mathrm{pH} 7.9$ in water extract, $0.96 \%$ organic matter content) with a very low DTPA-extractable $\mathrm{Zn}$ concentration $\left(0.11 \mathrm{mg} \mathrm{kg}^{-1}\right)$ increased the $\mathrm{Zn}$ concentrations of shoots and seeds in both species. Zuo and Zhang (2008) reported that $\mathrm{Fe}, \mathrm{Zn}$, and $\mathrm{Cu}$ concentrations of intercropped grown peanut increased significantly compared to those in monocropping both in the greenhouse and field. Systemic mechanisms may be involved in adaptation to nutrient stresses at the whole plant level. A reasonable intercropping system of nutrient efficient species should be considered to prevent or mitigate iron and zinc deficiency of plants in agricultural practice (Zuo and Zhang, 2009).

The effect of crop rotation on the available and total micronutrient contents in soils is somewhat different (Wei et al., 2006). Total nutrient content is affected mainly by crop uptake, and therefore the magnitude of the decrease depends on crop type and uptake intensity.

\section{DEVELOPING MICRONUTRIENT-EFFICIENT GENOTYPES: A NEW STRATEGY}

\subsection{Definition of nutrient efficiency}

According to the Soil Science Society of America (1997), nutrient efficiency is the ability of a plant to absorb, translocate, or utilize more of a specific nutrient than other plants under conditions of relatively low nutrient availability in the soil or growth media. This is the agronomic focus rather than the food quality focus which will be discussed below. Graham (1984) defined plant nutrient efficiency as the ability of a genotype to produce a high yield under conditions in which a soil nutrient is growth-limiting. Blair (1993) defined plant nutrient efficiency as the ability of a plant to acquire nutrient from a growth medium and/or to utilize it in the production of shoot and root biomass or grain. According to Isfan (1993), efficient genotypes are those with high ability to absorb nutrients from soil and fertilizer, produce high grain yield per unit of absorbed nutrient and store relatively little nutrients in the straw. As defined by Clark (1990), an efficient genotype is one that produces more dry matter or has a greater increase in the harvested parts per unit time, area, or applied nutrient, has less deficiency symptoms, or has greater incremental increases and higher concentrations of mineral nutrients than other genotypes grown under similar conditions. Gourley et al. (1994) proposed that the nutrient requirement of an efficient germplasm is less than an inefficient germplasm. Fageria et al. (2008) defined a nutrient efficient genotype as a genotype that produces higher economic yield with a determined quantity of applied or absorbed nutrient than other genotypes under similar growing conditions.

Nutrient efficiency emphasizing utilization is generally defined as total plant biomass produced per unit nutrient absorbed, which is equivalent to the reciprocal of the nutrient concentration of the entire plant (Gourley et al., 1994). This often is called the 'nutrient efficiency ratio' and has been used extensively to describe the internal nutrient requirement, particularly of $\mathrm{P}$, in many agronomic plant species (Baligar et al., 1990; Glass, 1989; Godwin and Blair, 1991). Using this definition, P-efficient alfalfa genotypes with higher shoot $\mathrm{P}$ concentration are selected to overcome $\mathrm{P}$ nutrition limitations in cattle (Miller et al., 1987).

The reciprocal of nutrient concentration does not consider the crop yield. Siddiqi and Glass (1981) suggested "utilization efficiency" defined as the product of yield times the reciprocal of nutrient concentration. The nutrient uptake per unit root length, surface area, or weight has also been defined as "uptake efficiency" (Buso and Bliss, 1988). In most studies, micronutrient efficiency has been calculated as the ratio of yield (shoot dry matter or grain yield) produced under micronutrient deficiency (-M) to yield produced with micronutrient fertilization $(+\mathrm{M})$, as follows (Graham, 1984):

Micronutrient efficiency $=($ yield $-\mathrm{M} / \mathrm{yield}+\mathrm{M}) \times 100$

In this paper, the last definition is considered as the main definition of micronutrient-efficiency for separating micronutrient-efficient and inefficient genotypes. Such an index is used to select improved micronutrient-efficient genotypes in a breeding program, or to provide information on qualities of commercial cultivars for growers.

\subsection{Micronutrient-efficient genotypes and crop productivity}

Application of fertilizers is not a totally successful strategy in alleviating micronutrient deficiency because of agronomic, economic, and environmental (Mortvedt, 1994; Graham and Rengel, 1993; Hacisalihoglu, 2002).

A more efficient and sustainable solution to micronutrient deficiency limitations to crop production is the development and use of micronutrient-efficient plant genotypes that can more effectively grow on soil with low phytoavailable micronutrient contents, which would reduce fertilizer inputs and protect the environment as well. Selection of plant genotypes that can tolerate low nutrient supply may increase productivity on low fertility soils and reduce fertilizer requirements (Gourley et al., 1994). 
One of the most important adaptive responses for crop plants involves their ability to deal with soil-mediated abiotic stresses involving deficient levels of micronutrients in the soil. Plant species vary significantly in tolerance to micronutrients deficiency stress; some are able to cope with low micronutrients availability, and thus, grow well even when other species or cultivars suffer reduced yield due to micronutrient deficiency (Graham and Rengel, 1993).

Exploiting genetic diversity of plants for enhanced productivity in poor fertility soils is a desirable and important objective in order to meet food demands for an increasing world population. Variation among plant germplasm in the ability to acquire nutrients from the soil has been investigated for decades (Godwin and Blair, 1991). There are several key mechanisms that could be involved in nutrient efficiency (Baligar et al., 2001; Fageria and Barbosa Filho, 2001; Fageria and Baligar, 2003; Khoshgoftarmanesh et al., 2004a, 2006a), including root processes that increase the bioavailability of soil nutrient for root uptake; enhanced root uptake and translocation of nutrients from the root to the shoot; altered subcellular compartmentation of nutrient in shoot cells; and more efficient biochemical utilization of nutrients in cells of the shoot. Many possible processes for control of nutrient efficiency have been investigated. In recent years, more attention has been paid to micronutrient efficiency.

Micronutrient efficiency is genetically controlled and the physiological and molecular mechanisms of micronutrient efficiency of plants are just beginning to be understood. Large ranges of genotypic variation in response to micronutrients deficiency stress have been reported in different plant species, particularly in cereals (Graham et al., 1992; Cakmak et al., 1997a, 1998). Such large variation is promising for developing plant genotypes that are more efficient in root uptake, translocation from root to shoots and/or internal utilization of micronutrients. Micronutrient-efficient genotypes may provide a number of other benefits, such as reductions in the use of fertilizers, improvements in seedling vigor, resistance to pathogens, and enhancement of grain nutritional quality (Graham and Rengel, 1993; Bouis, 1996; Graham and Welch, 1996).

Selecting and breeding staple food crops which are more efficient in the uptake of trace minerals from the soil and load more trace minerals into their seeds combines benefits both for agricultural productivity and human nutrition. This approach may have important applications for increasing farm productivity in developing countries in an environmental-friendly way (Cary et al., 1994; Kannenberg and Falk, 1995). Growing nutrient-efficient genotypes on soils with low nutrient availability would reduce land degradation by reducing the use of machinery (Thongbai et al., 1993) and by minimizing application of chemicals such as fertilizers on agricultural land (Rengel, 2001).

Beneficial effects of micronutrient-efficient crop genotypes for agricultural productivity result in extremely high cost/benefit ratios for investing in this type of micronutrient intervention. Furthermore, the adoption and spread of micronutrient enriched seeds by farmers can be driven by profit incentives because micronutrient enriched seeds increase crop productivity when planted in micronutrient-poor
Table I. Response of five wheat genotypes with different zinc efficiency to salinity and zinc application treatments (Khoshgoftamanesh et al., 2006a).

\begin{tabular}{lccccc}
\hline \multirow{2}{*}{$\mathrm{NaCl}$ rate $(\mathrm{mM})$} & \multicolumn{5}{c}{ Shoot dry matter yield $\left(\mathrm{g} \mathrm{pot}^{-1}\right)$} \\
\cline { 2 - 6 } & Dur-3 & Kavir & Falat & Rushan & Cross \\
\hline \multirow{5}{*}{ Without Zn } \\
60 & 69.1 & 82.6 & 94.1 & 92.9 & 99.6 \\
120 & 59.3 & 75.4 & 63.1 & 85.5 & 85.3 \\
180 & 50.2 & 55.3 & 61.3 & 69.5 & 80.4 \\
& 30.6 & 49.1 & 43.5 & 68.1 & 58.5 \\
0 & \multicolumn{5}{c}{ With Zn } \\
60 & 80.5 & 116.5 & 98.6 & 93.3 & 100.8 \\
120 & 77.1 & 92.1 & 77.5 & 87.2 & 89.6 \\
180 & 76.3 & 84.3 & 68.2 & 79.6 & 88.1 \\
\hline
\end{tabular}

soils (Graham et al., 2001). The benefits can be disseminated widely and they are sustainable once developed unlike current micronutrient interventions that rely on supplementation or food fortification (Graham et al., 2001, 2000; Welch et al., 1997).

Developing plants with a high ability to extract transition metal nutrients from soils may be more useful for $\mathrm{Fe}$ and $\mathrm{Mn}$. Soils which cause deficiency contain substantial levels of total $\mathrm{Fe}$ or Mn, but the minerals are not phytoavailable to traditional genotypes. Induced iron deficiency chlorosis is widespread and is a major concern for plants growing on calcareous or alkaline soils due to their high $\mathrm{pH}$ and low availability of iron (Welch et al., 1991; Marschner, 1995). In calcareous soils, $\mathrm{Fe}$ and $\mathrm{Mn}$ rapidly convert to immobile forms and generally several foliar applications are required to prevent deficiencies throughout the growing season. Selecting or breeding iron efficient genotypes of corn, soybean, sorghum and rice is considered the best way for correcting Fe deficiency stress on calcareous soils (Graham, 1984; Fageria and Baligar, 2003). Soil application of $\mathrm{Cu}, \mathrm{Zn}$, and $\mathrm{Mo}$ is more efficient than $\mathrm{Mn}$ and Fe fertilization, on most soils, but all transition metal nutrients are not readily translocated within plants on deficient soil (Nable and Webb, 1993; Graham and Webb, 1991).

Several studies have been done to select and breed cultivars with greater abilities to cope with adverse soil conditions. Micronutrient-efficient genotypes were described that have the ability to take up and utilize nutrients more efficiently under abiotic and biotic stresses (Pessarakli, 1999; Alam, 1999; Baligar et al., 2001) or that some micronutrientefficient genotypes can tolerate abiotic and biotic stresses (Fageria et al., 2008; Khoshgoftarmanesh, 2004a, 2006a, b; Marschner, 1995). Plant crop yield under stress could be enhanced by selection or breeding of plants that have high micronutrient efficiency, and ability to interact effectively with environmental extremes (Fageria et al., 2008). For example, Khoshgoftarmanesh et al. (2004a, b, 2006a, b) and Khoshgoftar and HajiMozaffari (2006) reported that zinc application in a severely calcareous saline soil increased the salt tolerance of wheat genotypes. Zinc-efficient genotypes are reported to be more tolerant to salinity than $\mathrm{Zn}$-inefficient genotypes (Tab. I). Bagci et al. (2007) indicated that sensitivity 
to $\mathrm{Zn}$ deficiency stress became more pronounced when wheat plants were drought-stressed. The effect of irrigation on grain yield was maximized when $\mathrm{Zn}$ was adequately supplied. Close relationship between water use efficiency and $\mathrm{Zn}$ nutritional status of plants has also been suggested (Bagci et al., 2007).

Plant nutrition status may greatly affect predisposition of plants to attack by, or effect of pests and diseases (Fageria et al., 2008). Micronutrient deficiencies reduce the plant tolerance to diseases and insects (Marschner, 1995). The fungicidal effect of manganese $(\mathrm{Mn})$, copper $(\mathrm{Cu})$ and zinc $(\mathrm{Zn})$ are wellknown as they have been common constituents of fungicides (Streeter et al., 2001). Copper, B, and Mn are involved in the synthesis of lignin, and phenolic compounds. Silicon plays a role in producing physical barriers against pathogen penetration (Barker and Pilbeam, 2007; Graham and Webb, 1991).

Streeter et al. (2001) reported that $\mathrm{Zn}$-sufficient plants are more tolerant to the effects of root pruning by the fungus than $\mathrm{Zn}$-deficient plants probably due to fungitoxicity of $\mathrm{Zn}$ and the role of $\mathrm{Zn}$ in the integrity or stability of the host plant's membranes. The increased root exudation by $\mathrm{Zn}$-deficient plants may accelerate the root-rot disease (Thongbai et al., 1993). A relationship between $\mathrm{Zn}$ nutrition and severity of some rootrot diseases has been demonstrated in wheat (Thongbai et al., 1993) and medic plants (Streeter et al., 2001). Streeter et al. (2001) suggested that $\mathrm{Zn}$ application does not directly inhibit infection by Rhizoctonia solani, nor reduce its pathogenicity, but it does strongly increase root growth. Zinc nutrition is beneficial in reducing the occurrence of phyllody virus in white clover (Carr and Stoddart, 1963), take-all in wheat (Brennan, 1992), and charcoal rot development in maize (Pareek and Pareek, 1999).

Silicon applications reduce the severity of fungal diseases such as blast and sheath blight of rice, powdery mildew of barley and wheat, and vermin damage of rice by the plant hopper in the field (Barker and Pilbeam, 2007). Plant genotypes with higher ability to absorb and/or utilize micronutrients seem to be more resistant to disease than micronutrientinefficient genotypes. The relationship between insect attacks and micronutrient-efficiency of plant genotypes needs further evaluation (Fageria et al., 2008).

Considerable progress has been made in breeding for $\mathrm{Zn}$, $\mathrm{Fe}$, and Mn efficient dicots and monocots and in identifying the genes involved (Marschner, 1995; Rengel, 2001). By comparing efficient and inefficient cultivars, some information on the genetic control of micronutrients efficiency has been obtained (Graham, 1984; Rengel, 2001). This information will accelerate development of more nutrient efficient crop plants by traditional and modern breeding techniques, and provide important information for genetic engineering.

\subsection{Micronutrient-efficient genotypes, crop quality and human health}

\subsubsection{Total concentration of micronutrients in plant based foods}

Different traditional public health interventions have been used to improve micronutrient nutritional status of the target population; i.e. supplementation, food diversification, industrial fortification and biofortification. Supplementation and industrial fortification have been effective in reducing morbidity and mortality resulting from micronutrient deficiencies worldwide, but infrastructure, purchasing power, or access to markets and healthcare systems is required in these approaches, often not available to poor people particularly in rural areas (Mayer et al., 2008).

Supplementation with pharmaceutical micronutrient preparations e.g. vitamin $\mathrm{A}$ and $\mathrm{Zn}$ capsules can be a rapid and effective way to alleviate micronutrient-deficiency on an individual basis. However, this strategy has generally failed on a population level in developing countries, due to lack of adequate infrastructure and education (Graham et al., 2000; Stein, 2006). For example, vitamin A supplementation programs covered up to $58 \%$ of target population over the last decades in 103 priority countries with a goal of preventing blindness caused by vitamin-A deficiency (UNICEF, 2007). Iron supplementation had little effect on the anemia problem in India, because of mismanagement, underfunding, logistic problems, and poor compliance (Vijayaraghavan, 2002).

Food fortification is a strategy that can be applied rather rapidly at the national level without changes in the dietary habits of people. As a public health measure, wheat flour is commonly fortified with iron, margarine with vitamin A and $\mathrm{D}$, and salt with iodine. However, $\mathrm{Zn}$ interventions with fortified foods or supplements are still largely experimental. Some countries also fortify wheat flour with zinc. Fortification of maize and wheat flours with $\mathrm{Fe}$ has been implemented in Mexico, Indonesia, and South Africa, but this approach still needs further evaluation (Gibson, 2006). Ahmed et al. (2008) concluded that fortification of whole wheat flour is feasible to alleviate $\mathrm{Fe}$ and $\mathrm{Zn}$ deficiency in vulnerable groups. A disadvantage of food fortification is that, like supplementation, its successful implementation into society requires safe delivery systems, stable policies, appropriate social infrastructures and continued financial support (White and Broadley, 2005; Gibson, 2006).

In the case that foods differ widely in available contents of micronutrients, dietary modification or diversification would seem a straightforward and sustainable way to combat micronutrients deficiency. But changes in dietary habits require individual and societal acceptance, as well as the availability of alternative foods at affordable prices. Poverty is another challenge that makes this strategy less applicable for poor countries.

Due to problems such as inadequate logistics, insufficient compliance, political instability and instability of funding, many of these interventions have failed. In particular, many of these programs never reached the majority of low-income women, infants and children in developing countries (Welch and Graham, 1999).

Using bioavailable micronutrient-dense staple crop cultivars is another approach that could be used to improve the micronutrient nutritional status of human (Bouis, 1996; Combs et al., 1996; Welch and Graham, 1999; Frossard et al., 2000; Welch, 2002). Cultivation of micronutrient-efficient crop genotypes holds great promise for making a significant, 
Table II. Range and mean concentrations of Fe and $\mathrm{Zn}$ in the shoot and grain of different wheat genotypes in the presence and absence of added $\mathrm{Zn}$ fertilizer (Khoshgoftarmanesh et al., 2007).

\begin{tabular}{lcccc}
\hline & \multicolumn{4}{c}{ Concentration $\left(\mu \mathrm{g} \mathrm{g}^{-1}\right)$} \\
\cline { 2 - 5 } & \multicolumn{3}{c}{ Zn } & \multicolumn{3}{c}{ Fe } \\
\cline { 2 - 5 } & Minus Zn & Plus Zn & Minus Zn & Plus Zn \\
\hline \multirow{5}{*}{ Range } & $5.5-21.3$ & Shoot & & \\
Mean & 9.26 .0 & $15.0-98.0$ & $14.3-101.0$ \\
& \multicolumn{5}{c}{59.5} \\
Range & $4.6-41.4$ & Grain & 57.1 & 59.6 \\
Mean & 9.8 & 11.8 & $8.5-75.8$ & $9.7-84.1$ \\
\end{tabular}

low-cost, and sustainable contribution to reducing micronutrient, particularly mineral deficiencies in humans.

This strategy, for which the term "biofortification" has been coined, has the potential to be sustainable as well as economical. Biofortification is based on the principle that health comes from the farm, not the pharmacy (Mayer et al., 2008). Like fortification in general, it does not require people to change their dietary habits. This approach is attractive for the farmer because of increased yields and reduced seedling losses and does not require special infrastructure. In addition, the output of this program can be distributed to the remote rural areas where poor populations are living at low cost (Graham et al., 2000; Yang et al., 2007).

Biofortification can be achieved (i) by breeding or genetic engineering crop plants with improved ability to accumulate target micronutrients in potentially bioavailable form in edible plant parts (Graham et al., 2000; Welch and Graham, 2004; White and Broadley, 2005), (ii) by increasing (bioavailable) micronutrient density in food plants by agricultural methods of crop cultivation, for example by fertilizer application or by amendments that increase the element's bioavailability in the soil for plant uptake (Frossard et al., 2000; Graham et al., 2001; Welch, 2002).

Most modern cultivars of wheat and rice have a lower concentration of micronutrients in grain than traditional cultivars because breeders generally focused on increasing yield, with no attention to the micronutrient concentrations in grain. Breeding micronutrient-dense cultivars of staple foods is a powerful tool to combat micronutrient malnutrition. Recent findings show that it is possible to breed for enhanced levels of iron, zinc and provitamin A carotenoids in edible tissues of rice, wheat, maize, beans and cassava (Graham et al., 2001). Recently, the international genomes of rice (Oryza sativa L.), wheat (Triticum aestivum L. and T. durum Desf.), maize (Zea mays L.), beans (Phaseolus vulgaris L.), cassava (Manihot esculenta Crantz) and sweet potato (Ipomoea batatas, L.) have been surveyed for high micronutrient density traits (Graham et al., 2001).

Large variation in the grain micronutrients concentration e.g. Fe and $\mathrm{Zn}$ in different wheat genotypes has been reported (Cakmak, 2002; Graham et al., 1999; Kalayci et al., 1999; Khoshgoftarmanesh et al., 2004a, 2006a, b). As shown in Table II, different wheat genotypes vary greatly in grain $\mathrm{Zn}$ and
Fe concentrations, ranging from 8.5 to $84 \mu \mathrm{g} \mathrm{g}^{-1}$ for $\mathrm{Fe}$ and 4.6 to $41.4 \mu \mathrm{g} \mathrm{g}^{-1}$ for $\mathrm{Zn}$ (Khoshgoftarmanesh et al., 2007). The large genetic variation found in $\mathrm{Fe}, \mathrm{Zn}, \mathrm{Mn}$, and Se concentrations among geotypes in the major germplasm banks is sufficient to justify the possibility of developing micronutrientefficient genotypes. Thus, it seems feasible for crop breeders to select for high micronutrients density traits in breeding programs.

Modern recombinant DNA technology can also be used to enhance the nutritional quality of food crops such as increasing the amount and bioavailability of micronutrients in plants (DellaPenna, 1999; Frossard et al., 2000; Goto et al., 1999, 2000; Lucca et al., 2001). For example, recombinant DNA technology was used to improve the provitamin A content of rice-grain endosperm in 'Golden rice' (Ye et al., 2000). Goto et al. (1999) transformed rice plants using a phytoferritin (a major protein storage form of $\mathrm{Fe}$ in plants) gene from soybean and a rice endosperm promoter gene to enrich $\mathrm{Fe}$ in the rice-grain endosperm. Lucca et al. (2001) also enriched the Fe concentration in rice-grain endosperm using the phytoferritin gene from pea plants.

The strategy of breeding for mineral and vitamin enhancement of staple foods has several complementary advantages. Micronutrient-dense crop genotypes deploy micronutrients to consumers through the traditional ways with no necessity for changes in consumers' behavior (Mayer et al., 2008). The consistent daily consumption of large amounts of food staples by all family members is another benefit of this approach. Nevertheless, any intervention to improve micronutrient status must target women, children, and adolescents because of their elevated needs for minerals and vitamins (Nicklas, 1995).

Biofortification programs for $\beta$-carotene, iron, and zinc have been estimated to be cost-effective (Neidecker-Gonzales et al., 2007; Stein et al., 2007). Investments in plant-breeding research are much less than those in supplementation and fortification programs because the increased value persists after development. In addition, supplementation and fortification programs must be sustained and thus, much more investment is needed in these programs. If investments are not sustained, benefits disappear. Development of iron- and zinc-dense cultivars of rice or wheat might cost as much as $\$ 10$ million each over 10 years, including the costs of nutrition efficacy tests, the costs of dissemination in selected regions, and the costs of a nutrition and economic impact evaluation. Moreover, benefits are sustainable at low maintenance costs.

However, before beginning extensive breeding programs, it is essential to confirm that the micronutrient is sufficiently well absorbed and utilized by human consumers. In fact, further research is needed to determine if the edible portions of micronutrient dense crop grains still retain enriched levels of micronutrients after milling and processing, and if enriched levels of micronutrients in grain are bioavailable to target human populations.

Agronomic biofortification is required for optimizing and ensuring the success of genetic biofortification of cereal grains with $\mathrm{Zn}$ and Se (Broadley et al., 2006; Cakmak, 2008). In case of greater bioavailability of the grain $\mathrm{Zn}$ derived from foliar applications than from soil, agronomic biofortification 
would be a very attractive and useful strategy in solving $\mathrm{Zn}$ deficiency-related health problems globally and effectively (Cakmak, 2008). In fact, agronomic biofortification strategy appears to be essential in keeping sufficient amount of available $\mathrm{Zn}$ in soil solution and maintaining adequate $\mathrm{Zn}$ transport to the seeds during reproductive growth stage (Cakmak, 2008).

\subsubsection{Bioavailability of micronutrients in food}

Although increasing the concentration of micronutrients in plant foods is necessary, the absorption and utilization (i.e., bioavailability) of micronutrients in meals containing plant foods may be also improved (Graham and Welch, 1996). Plant foods contain various substances that interact with micronutrients. Some, called antinutrients, reduce whereas others, called promoters, enhance micronutrient bioavailability to humans (Graham et al., 2001). These substances can be also manipulated by agricultural practices (Graham et al., 2001) and by genetic manipulation (Lucca et al., 2001).

The nutritional value of a diet can not be determined solely from the total contents of individual nutrients. Concentrations of antinutrients and promoters as well as interactions between nutrients affect bioavailability, which is the amount of nutrient absorbed from the diet (Graham et al., 2000). In fact, the fraction of micronutrient content in food that is available for absorption by the human gastro-intestinal tract depends on the presence of other food ingredients. A number of nutrient promoters and antinutrients has been found. Research on the potential role of a variety of substances to act as promoters or antinutrients of some micronutrients such as $\mathrm{Fe}$ and $\mathrm{Zn}$ bioavailability to humans has been reviewed by House (1999). There is evidence for a promoter function of certain chelating low-molecular-weight organic acids as well as amino acids. Drakakaki et al. (2005) concluded that the expression of recombinant ferritin and phytase could help to increase iron availability and enhance the absorption of iron, particularly in cereal-based diets that lack other nutritional components. Phytate, tannins and other polyphenols, and some heavy metals act as antinutrients (Frossard et al., 2000; Graham et al., 2001).

Plant crop genotypes differ not only in grain micronutrient concentrations but also in the amounts of antinutrients and promoters in their seeds. For example, phytate concentration strongly depends on the plant genotype (Cakmak and Marschner, 1986; Khoshgoftarmanesh et al., 2007; Marschner, 1995, Torun et al., 2001). Erdal et al. (2002) found differences in phytate content of grain in 20 different wheat cultivars grown on a $\mathrm{Zn}$-deficient calcareous soil $\left(0.10 \mathrm{mg} \mathrm{kg}^{-1}\right.$ DTPA-extractable $\mathrm{Zn}$ ) in central Anatolia. Zinc fertilization (23 $\mathrm{kg} \mathrm{ha}^{-1} \mathrm{Zn}$ applied as $\mathrm{ZnSO}_{4}$ ) increased seed $\mathrm{Zn}$ concentration in all cultivars and reduced seed phytate in the majority of the cultivars. The average increase in seed $\mathrm{Zn}$ was from 8.8 to $16.7 \mathrm{mg} \mathrm{kg}^{-1}$, while phytate decreased in average from 10.7 to $10.0 \mathrm{mg} \mathrm{g}^{-1}$ grain dry weight. Raboy et al. (1991) showed the existence of an important variation in phytate-P among four wheat cultivars and their $60 \mathrm{~F} 6$ lines. Barrier-Guillot et al. (1996) reported that phytate-P in seeds of four wheat cultivars varied between 0.92 and $2.80 \mathrm{~g} \mathrm{~kg}^{-1}$ DW. The range
Table III. The range and mean molar ratio of phytic acid to $\mathrm{Zn}$ in grains of selected wheat genotypes in the absence and presence of added Zn (Khoshgoftarmanesh et al., 2007).

\begin{tabular}{lcccc}
\hline & \multicolumn{4}{c}{ Phytic acid/Zn molar ratio } \\
\cline { 2 - 5 } & Minus Zn & Plus Zn & Minus Zn & Plus Zn \\
\hline Range & $39-88$ & $43-76$ & $27-49$ & $18-37$ \\
Mean & 48 & 31 & 29 & 26 \\
\hline
\end{tabular}

and mean concentration of $\mathrm{Zn}$ and molar ratio of phytateto- $\mathrm{Zn}$ in selected Iranian wheat genotypes are shown in Table III. The genotypic variability in seed phytate concentration of wheat genotypes indicates that this variation can be exploited for breeding genotypes with low phytate concentrations to improve $\mathrm{Zn}$ bioavailability in cereal-based foods although attention should be paid to the fact that low phytate content increases the possibility of cancers. In addition, phytate is required for seed germination.

In most cases, phytate-to- $\mathrm{Zn}$ molar ratios in foods are considered a predictor of Zn bioavailability (Gargari et al., 2007). This index has been used widely (Gibson et al., 2003; International Zinc Nutrition Consultative Group-IZiNCG, 2004), and it is considered as a good index for zinc bioavailability by the World Health Organization (World Health Organization, 1996) and International Zinc Nutrition Consultative Group (International Zinc Nutrition Consultative Group-IZiNCG, 2004).

\subsection{Combining the benefits of high yield and better nutritional quality}

An important question in development of micronutrientefficient genotypes is the possibility of combining high yield with better micronutrient nutritional quality. Previous studies showed that it is possible to combine micronutrient-rich traits with high yield. Both seedling vigor and nutritional quality can be improved through genetically modifying seeds with micronutrient enrichment traits. The highest micronutrient densities, which are approximately twice as high as those popular modern cultivars and indicating the existing genetic potential, can be successfully combined with high yield.

The combining of benefits for human nutrition and agricultural productivity, resulting from breeding staple food crops which are more efficient in the uptake of trace minerals from the soil and which load more trace minerals into their seeds, results in extremely high benefit-cost ratios for investments in agricultural research in this area. This approach would be more valuable and cost-effective by estimating the costs paid to heal micronutrient malnutrition in developing countries. Some adverse effects of $\mathrm{Zn}$ and Fe deficiency cannot be remediated by supplying adequate levels of $\mathrm{Zn}$ or Fe later in childhood, so prevention needs to be the focus of this seed improvement program.

High trace mineral density in seeds produces more viable and vigorous seedlings in the next generation, and efficiency in the uptake of trace minerals improves disease resistance, agronomic characteristics which improve plant nutrition and 
productivity in micronutrient deficient soils (Welch, 1999; Yilmaz et al., 1998). Adoption and spread of nutritionallyimproved varieties by farmers can rely on profit incentives, either because of agronomic advantages on trace mineral deficient soils or incorporation of nutritional improvements in the most profitable varieties being released (Harris et al., 2008).

It has been shown that wheat plants grown from seed with high $\mathrm{Zn}$ content can achieve higher grain yields than those grown from the low- $\mathrm{Zn}$ seed when $\mathrm{Zn}$ was not applied to the soil (Yilmaz et al., 1998). Therefore, sowing seeds with higher $\mathrm{Zn}$ contents can be considered a practical solution to alleviate plant $\mathrm{Zn}$ deficiency especially under rainfed conditions, in spite of it being insufficient to completely overcome the problem (Yilmaz et al., 1998).

Mineral-packed seeds sell themselves to farmers because these trace minerals are essential in helping plants resist disease. More seedlings survive and initial growth is more rapid. Ultimately, yields are higher, particularly on trace mineral "deficient" soils in arid regions. Because roots extend more deeply into the soil and so can tap more subsoil moisture and nutrients, the mineral-efficient varieties are more drought-resistant and so require less irrigation. And because of their more efficient uptake of existing trace minerals, these varieties require lesser chemical inputs. Thus, the new seeds can be expected to be environmentally beneficial as well. It is conceivable that seed priming by spraying seed fields with $\mathrm{Fe}$ and $\mathrm{Zn}$ fertilizers during grain filling will provide enough additional yield benefit to justify additional seed price. But this approach is insufficient to improve the density of bioavailable micronutrients in grain of crops grown with "primed" seed. Several different commercial practices may be beneficial to improve plant production despite low levels of soil micronutrients in many nations.

\subsection{Need to limit grain $\mathrm{Cd}$ and As while improving levels of $\mathrm{Zn}$ and $\mathrm{Fe}$ in crops}

In contrast with the essential nutrients $\mathrm{Zn}$ and $\mathrm{Fe}$, cadmium $(\mathrm{Cd})$ in soils can be accumulated to levels in rice and some other crops that are dangerous to consumers (Chaney et al., 2004). In areas of Asia where mine wastes contaminated rice paddy soils, rice accumulated Cd to levels over $0.4 \mathrm{mg} \mathrm{kg}^{-1}$, the CODEX ALIMENTARIUS maximum recognized level safe for lifetime consumption by humans. In Japan, China and Thailand, mine-contaminated paddy soils have caused adverse effects in exposed subsistence farm families (Nogawa et al., 2004; Cai et al., 1998; Swaddiwudhipong et al., 2007). The nature of rice production and composition of polished rice grain contribute to the potential for this effect: (1) when flooded rice is drained at flowering, rapid drop in soil $\mathrm{pH}$ and transformation of $\mathrm{CdS}$ to more soluble forms allows rapid uptake of $\mathrm{Cd}$ to rice grain during grain filling; (2) polishing of rice removes much of the $\mathrm{Zn}, \mathrm{Fe}$ and $\mathrm{Ca}$ in brown rice; levels present in polished grain are insufficient to support human health; and (3) subsistence farming individuals may consume home-grown rice for their lifetime, allowing accumulation in the kidney over time until injury occurs. Although other crops require consideration regarding transfer of soil Cd to humans, western populations have not been found to suffer $\mathrm{Cd}$ diseases, perhaps because few consume home-grown staple foodstuffs grown in contaminated soils for their lifetime. Further, most soil Cd is accompanied by 200 -fold higher $\mathrm{Zn}$, so higher $\mathrm{Zn}$ tends to limit $\mathrm{Cd}$ uptake into edible crop tissues (Chaney et al., 2004).

Two aspects of breeding Fe and $\mathrm{Zn}$ improved crops should consider the potential for $\mathrm{Cd}$ accumulation. First, cultivars vary in $\mathrm{Cd}$ accumulation due to genetic variation (Grant et al., 2008); normal breeding practices can produce higher Cd progenies by chance alone. In general, $\mathrm{Cd}$ has been found to enter plants on the root $\mathrm{Zn}$-transporters (Hart et al., 2002). Thus breeding to increase $\mathrm{Zn}$ uptake may cause increased $\mathrm{Cd}$ accumulation as well. Transport to grain of $\mathrm{Cd}$ and $\mathrm{Zn}$ are somewhat independent, so it is possible to achieve both higher $\mathrm{Zn}$ and $\mathrm{Cd}$ uptake but only higher $\mathrm{Zn}$ movement to grain. Breeding programs to improve grain $\mathrm{Zn}$ and $\mathrm{Fe}$ should check to assure that $\mathrm{Cd}$ is not being increased along with $\mathrm{Zn}$. In the same way, breeding to increase aluminum tolerance to allow production in strongly acidic soils will tend to increase uptake of $\mathrm{Cd}$ and other divalent cations (McLaughlin et al., 1999). Breeders of acid tolerant crops need to assure that their new cultivars are not also increased in $\mathrm{Cd}$.

Arsenic (As) is usually independent of grain $\mathrm{Fe}$ and $\mathrm{Zn}$, but recent issues of As in irrigation water and rice require similar effort to consider the potential for As accumulation in grain. Because rice is grown in flooded soils, and flooding produces arsenite which is more soluble, more phytotoxic, and more accumulated by rice, using high As waters to produce rice may produce grain with excessive As for lifetime consumption by humans (Meharg, 2004; Abedin et al., 2002). For rice cultivars to be grown on such As enriched soils, breeding lower As accumulating genotypes may be critical to the continued success of agriculture (Williams P.N. et al., 2005).

\subsection{Challenges in programs for selecting or breeding micronutrient-efficient genotypes}

Many different definitions for efficiency make the use of the term ambiguous. These differences in defining nutrient efficiency makes it difficult to compare results of different studies particularly by considering that nutrient efficiency is influenced by other factors, such as soil fertility status, climate, crop rotations, and management practices (Stewart et al., 2005). Gerloff and Gabelman (1983) proposed that genotypes differing in yield under nutrient stress should only be designated efficient or inefficient if they are normal in appearance and have similar yields when an optimal amount of the nutrient is available. To reduce the confounding effects that other factors have on nutrient efficiency, Gourley et al. (1994) proposed that equivalent yields of genotypes be demonstrated where nutrients are not limiting. This advise has not been widely followed by researchers; plant species and cultivars with significantly different genetic potentials have been compared for their nutrient efficiency. Figure 1 shows models of the response of three plant varieties with different potential yield to different 


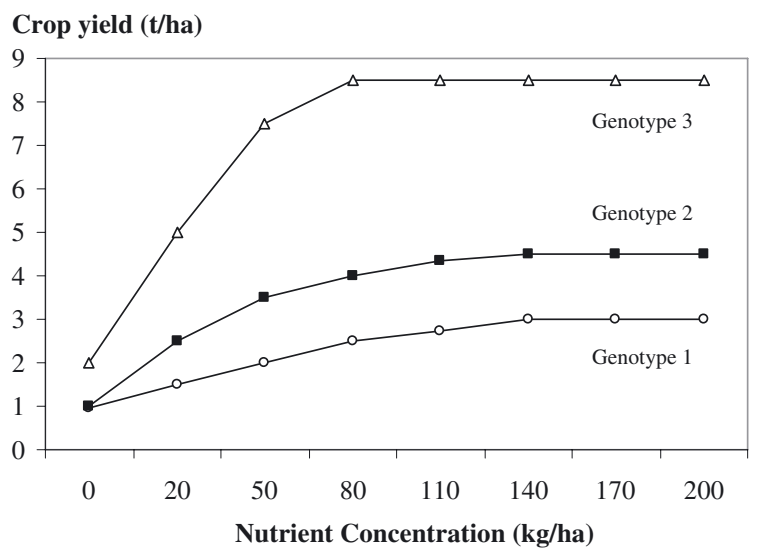

Figure 1. Suggestive response of three different plant varieties to nutrient concentration in media. Genotype 3 produced the highest yield under non-stress conditions while its nutrient efficiency, determined as commonly used efficiency definition, is less than other genotypes. In contrast, the most nutrient-efficient Genotype 1 had the lowest yield when an optimal amount of the nutrient is available.

soil nutrient levels. These plant varieties have different yields in the presence of an optimal amount of the nutrient. The plant variety 3 produced the highest yield under non-stress conditions while its nutrient efficiency, determined as commonly used efficiency definition, is less than other varieties. In contrast, the most nutrient-efficient variety 1 had the lowest yield when an optimal amount of the nutrient is available.

One of the major difficulties with breeding for resistance to nutrient deficiency is that the stress condition is frequently assessed based only on plant growth. However, growth is as a very complex character influenced by different inter-related processes. Therefore, growth is not a suitable parameter for distinguishing causes and effects of micronutrient deficiency stress.

Better screening techniques need to be developed by targeting specific processes that promote micronutrient deficiency, rather than those that appear as a consequence of it. It is expected that in the near future molecular methods will dominate selection for nutrient efficiency. Development of molecular markers for regions of the genome segregating with the trait of a particular nutrient efficiency will be crucial in that respect. However, molecular markers may be population-dependent, making them unsuitable for use in breeding programs. Even in screening based on molecular methods, seed nutrient content may need to be measured to assure the effectiveness of the program (Rengel, 2001).

Identification of genotypes with differing nutrient efficiencies, by whatever definition, generally includes investigation of potential morphological, physiological, and biochemical mechanisms involved. These mechanisms have been well reviewed (Caradus, 1990; Sauerbeck and Helal, 1990). However, it is often difficult to separate cause from effect when evaluating potential mechanisms of efficient nutrient uptake and utilization. Mechanisms conferring micronutrient efficiency are diverse and complex. Considering the close relationship between the root and shoot activities, differences in yield or nutrient accumulation by plants may incorrectly be attributed to differences in root morphology and function (Gourley et al., 1994).

Another challenge in breeding programs for assessment of a large number of genotypes is that field testings are timeconsuming and expensive. Therefore, simple, fast and inexpensive techniques rather than expensive field experiments are required (Graham, 1984; Graham and Rengel, 1993). At this date, valid field screening is still needed before improved cultivars can be identified. Although genes may be identified in laboratory and greenhouse programs, incorporating micronutrient efficiency or density in grain with high yield and other agronomic performance measures will require field screening using traditional breeding approaches.

In most cases the crop yield has been considered as the main basis for separating micronutrient-efficient and inefficient genotypes (Clark, 1990; Stewart et al., 2005; Fageria et al., 2008). There is a concern whether or not micronutrientefficient genotypes with higher tolerance to micronutrient deficiency can accumulate more nutrients in their edible parts. Although micronutrient-efficient genotypes possess higher uptake capacity, they do not necessarily have higher micronutrient concentrations in their leaves or grains (Graham et al., 1992). Micronutrient-efficient genotypes may even contain lower micronutrient concentrations in their edible parts than micronutrient-inefficient genotypes (Cakmak et al., 1997a, b, 1998). Enhanced micronutrient uptake by efficient genotypes under micronutrient deficiency stress improves dry matter production and often results in decreased tissue micronutrient concentration (dilution effect) to levels similar to those present in micronutrient-inefficient genotypes (Marschner, 1995). For example, Cakmak et al. (1997a) reported that in Zn-deficient soil, the most $\mathrm{Zn}$-efficient rye had lower $\mathrm{Zn}$ concentration in its tissues than a $\mathrm{Zn}$-inefficient durum wheat. Khoshgoftarmanesh et al. (2006a) reported that $\mathrm{Zn}$-efficient wheat genotypes had lower shoot and grain $\mathrm{Zn}$ concentrations as compared to $\mathrm{Zn}$-inefficient genotypes although the total amount of $\mathrm{Zn}$ per shoot or grain was higher in Zn-efficient genotypes due to more shoot dry matter yield.

Two important questions need to be answered in programs for selecting or breeding micronutrient-efficient cultivars. The first question is whether there is stability in response to nutrient efficiency of plant genotypes in different environments or how do the interactions of genotype by environment $(\mathrm{G} \times \mathrm{E})$ affect response of genotypes to nutrient deficiency and fertilization condition? The second question regards relationships between crop productivity, mineral concentrations and other nutritional quality factors (e.g. concentrations of promoters and antinutrients) and the way that both crop productivity and grain quality aspects can be combined in developing new micronutrient-efficient genotypes.

Another important aspect that has to be considered in developing micronutrient-dense genotypes is that the bioavailability of micronutrients in enriched genotypes must be tested in humans to assure that they are of benefit to people preparing and eating them in traditional ways within normal household environments. Consumer acceptance must be tested (taste and cooking quality must be acceptable to household members) to assure maximum benefit to nutritional health. 


\subsection{Stress tolerance indicators for selecting micronutrient-efficient genotypes}

Micronutrient deficiencies are abiotic stresses for plant production and most researchers have considered micronutrient efficiency synonymous with plant tolerance to micronutrient deficiency stress. A better understanding of the stress tolerance indicators is required for developing more reliable screening procedures to identify and select genotypes with high micronutrient efficiency. Breeders have used several yield stability analyses for identifying tolerant and sensitive genotypes to different environmental stresses (Fernandez et al., 1989). A relatively severe deficiency of an essential nutrient can be considered as a stress for plants (Fernandez, 1991). The field stress environment is characterized primarily by low inputs, suboptimal levels of irrigation, nutrients, temperature, and plant protection measures (Blum, 1988). Selection of genotypes adapted to both stress and non-stress environments have been the main objective of several yield trials.

Selection criteria are proposed to select genotypes based on their performance in stress and non-stress environments (Rosielle and Hamblin, 1981) who defined stress tolerance (TOL) as the difference in crop yield between the stress $\left(\mathrm{Y}_{\mathrm{s}}\right)$ and non-stress environment $\left(\mathrm{Y}_{\mathrm{p}}\right)$, and mean productivity (MP) as the average yield of $Y_{s}$ and $Y_{p}$. Fischer and Maurer (1978) proposed a stress susceptibility index (SSI), expressed by the following relationship:

$$
\mathrm{SSI}=\left[1-\left(\mathrm{Y}_{\mathrm{s}} / \mathrm{Y}_{\mathrm{p}}\right)\right] / \mathrm{SI}
$$

where SI is the stress intensity and is estimated as [1 $\left.\left(\mathrm{Y}_{\mathrm{s}} / \mathrm{Y}_{\mathrm{p}}\right)\right]$, and where $\mathrm{Y}_{\mathrm{s}-}$ and $\mathrm{Y}_{\mathrm{p}-}$ are the mean yields over all genotypes evaluated under stress and non-stress conditions. Rosielle and Hamblin (1981) evaluated the genotypic selection based on mean productivity (MP) and stress tolerance (TOL) and showed that selection of genotypes based on stress tolerance was efficient in improving yield under stress conditions, whereas the selected genotypes performed poorly under nonstress environments.

The heritability for yield is sometimes higher in the nonstress environment compared with the stress environment (Frey, 1964). Generally, evaluation in the non-stress environment allowed a better expression of genotypic potential, with higher heritability estimate yield and yield components than genotypes evaluated under the stress environments. Genotype effect and its interaction with environment are usually higher under favorable conditions compared to stress environments because the non-stress environmental conditions allow the genotypes to express their maximum genetic potential.

Genotypes can be categorized based on their performance in stress and non-stress environments into four groups: (A) genotypes that are not affected by stress and produce the same in both stress and non-stress environments; (B) genotypes that produce high yield only in non-stress environments; (C) genotypes with high yield in stress condition and low yield in non-stress environment; (D) and genotypes with low yield in both stress and non-stress environments. The optimum criterion should be separation of Group A from the other three groups. However, the stress tolerance indicators, mean productivity, stress tolerance, and SSI, failed to distinguish Group A genotypes from the other three groups. Fernandez (1991) presented a new stress tolerance index, STI, which can be used to identify genotypes that produce high yields under both nonstress and stress environments.

The stress intensity (SI) is defined as:

$$
\mathrm{SI}=1-\left(\mathrm{Y}_{s-} / \mathrm{Y}_{p-}\right)
$$

where $\mathrm{Y}_{\mathrm{p}-}$ is the potential yield of a given genotype in a nonstress environment and $\mathrm{Y}_{\mathrm{s}-}$ is the yield of a given genotype in a stress environment. The stress index can take values between 0 and 1. The larger value of SI indicates more severe stress conditions. Mean productivity (Eq. (3)) favors higher yield potential and lower stress tolerance. Rosielle and Hablin (1981) showed that under most yield trials, the correlations between mean productivity and $Y_{p}$, as well as between mean productivity and $Y_{s}$, would be positive. Thus, selections based on mean productivity generally increase the average yield in both stress and non-stress environments. However, mean productivity can not distinguish between Group A and Group B genotypes.

$$
\mathrm{MP}=\left(\mathrm{Y}_{\mathrm{s}}+\mathrm{Y}_{\mathrm{p}}\right) / 2
$$

The tolerance index (TOL) is calculated by equation (4). A larger value of the tolerance index represents relatively more sensitivity to stress, thus a smaller value of tolerance index is favored. Selection based on tolerance index separates genotypes with low yield potential under non-stress conditions and high yield under stress conditions. The tolerance index fails to distinguish between Group C and Group A.

$$
\mathrm{TOL}=\mathrm{Y}_{\mathrm{p}}-\mathrm{Y}_{\mathrm{s}}
$$

The stress susceptibility index (SSI) is another indicator to screen genotypes. Smaller values of SSI indicate greater tolerance to stress. Under most yield trials tolerance index and stress susceptibility index are positively correlated. Selection based on stress susceptibility index (SSI) favors genotypes with low yield under non-stress and high yield under stress conditions. Thus, SSI also fails to distinguish Group A from Group C.

Geometric mean productivity (GMP) is a better indicator than MP to separate Group A and Group C.

$$
\mathrm{GMP}=\sqrt{ }\left(\mathrm{Y}_{\mathrm{s}} * \mathrm{Y}_{\mathrm{p}}\right)
$$

Fernandez (1991) proposed stress tolerance index (STI) given by the following equation

$$
\mathrm{STI}=\left(\mathrm{Y}_{\mathrm{p}}\right)\left(\mathrm{Y}_{\mathrm{s}}\right) /\left(\mathrm{Y}_{\mathrm{p}-}\right)^{2} .
$$

A high value of STI indicates great tolerance to stress and high potential yield. The stress intensity value is also incorporated in the estimation of STI. Thus, STI is expected to distinguish Group A from Group B and Group C.

Three-dimensional plots of $\mathrm{Y}_{\mathrm{s}}$ (x-axis), $\mathrm{Y}_{\mathrm{p}}$ (y-axis) and STI (z-axis) based on grain yield of different bread wheat genotypes grown under severely $\mathrm{Zn}$-deficient soil (stress condition) 


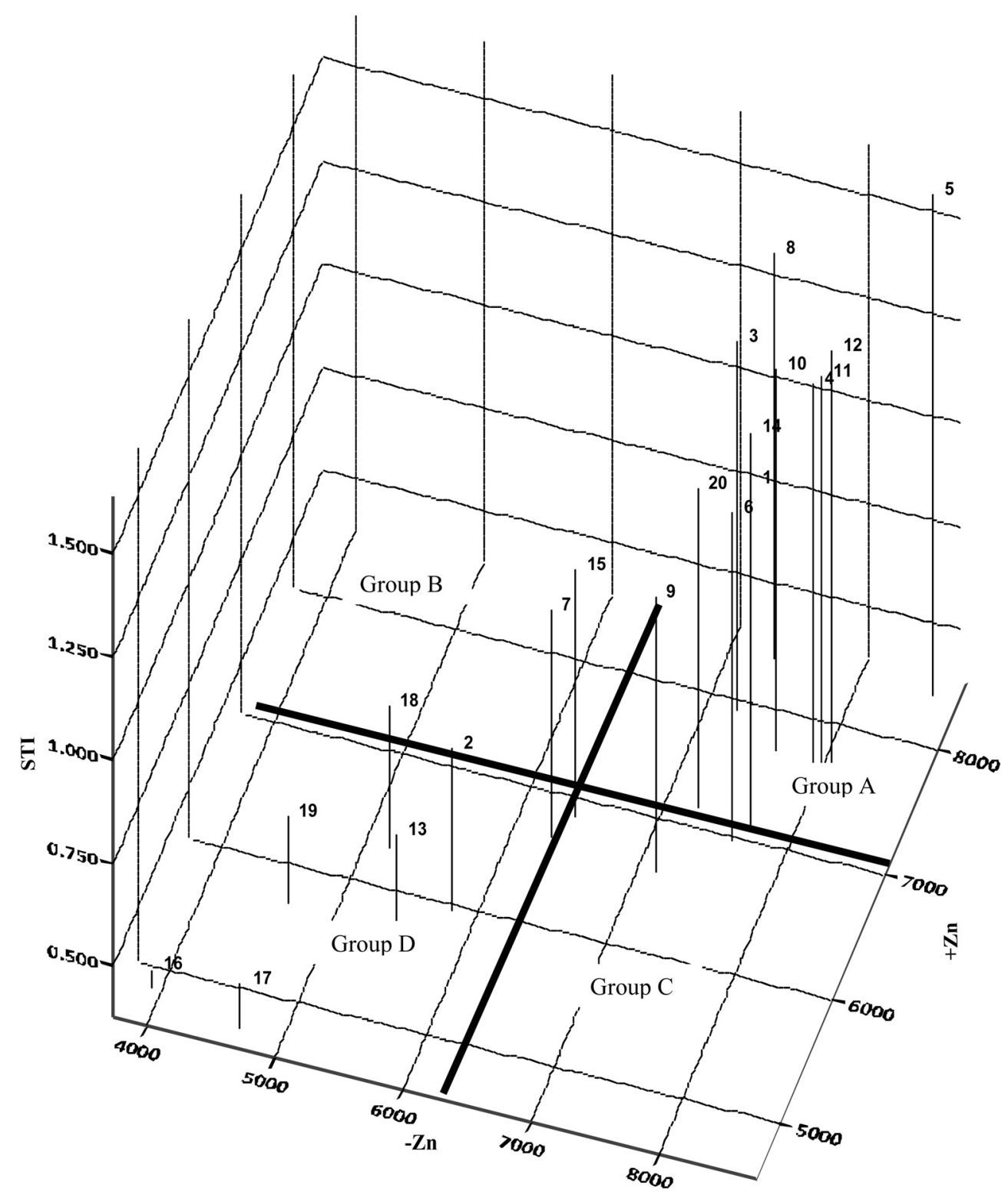

Figure 2. The 3-D plot among salt tolerance index (STI), -Ze and +Ze condition for different winter wheat cultivars. Group A, genotypes that are not affected by stress and produce the same in both stress and non-stress environments; Group B, genotypes that produce higher yield only in non-stress environments; Group C, genotypes with higher yield in stress condition and lower yield in non-stress environment; and Group D, genotypes with low yield in both stress and non-stress environments. Mahdavi (1), Bezostaya (2), Navid (3), Alamoot (4), Alvand (5), Zarin (6), MV-17 (7), Gaspard (8), Gascogen (9), Sayson (10), Shahriar (11), Toos (12), Sabalan (13), Roshan Winter Back Cross (14), Shahi Cross (15), Shahpasand (16), Omid (17), Azar2 (18), Sardari (19) and C-81-10 (20) (Khoshgoftarmanesh, not published).

and $\mathrm{Zn}$ fertilized soils (non-stress condition) is shown in Figure 2. The method presented by Fernandez (1991) was used to show interrelationships among these three variables, to separate the Group A genotypes from the other groups (Groups $\mathrm{B}, \mathrm{C}, \mathrm{D})$. To compare with the micronutrient efficiency index commonly used by plant nutritionists, a correlation was made between the STI and Zn efficiency of wheat genotypes. It seems that STI is a good selection criterion for identifying high-yield and stress-tolerant genotypes. The X-Y plane is divided into four regions by drawing intersecting lines through $\mathrm{Y}_{\mathrm{s}}$ and $\mathrm{Y}_{\mathrm{p}}$ and the four groups are marked as Group A to
Group D (Fig. 2). Most of the Group A genotypes showed high STI and genotypes in group D showed low STI values. Analysis of variance for grain yield and stress tolerance indices for wheat grown in zinc stress and non stress conditions indicates that the STI indicator is less affected by the environment and its stability is more than other indices (Tab. IV). Table V presents the calculated stress tolerance indices and mean grain yield of studied wheat genotypes grown in zinc stress and non stress conditions. Correlation coefficient between stress tolerance indices and yield in zinc stress and non stress conditions is also shown in Table VI. The values 
Table IV. Analysis of variance for grain yield and stress tolerance indices in wheat in zinc stress and non stress conditions. This table shows the effect of environment on different stress indices and their relative stability. GMP, STI, SSI, MP, TOL, EF, $\mathrm{Y}_{\mathrm{p}}$, and $\mathrm{Y}_{\mathrm{s}}$ are geometric mean productivity, stress tolerance index, stress susceptibility index, mean productivity, tolerance index, zinc-efficiency, grain yield under with added $\mathrm{Zn}$ treatment, and grain yield under without added $\mathrm{Zn}$ treatment, respectively.

\begin{tabular}{|c|c|c|c|c|c|c|c|c|c|}
\hline GMP & STI & SSI & MP & TOL & EF & $Y_{p}$ & $\mathrm{Y}_{\mathrm{S}}$ & $\mathrm{df}$ & Source of variation \\
\hline \multicolumn{10}{|c|}{$\operatorname{Pr}>F$} \\
\hline$<.0001$ & 0.4948 & 0.7774 & $<.0001$ & 0.9666 & 0.7154 & $<.0001$ & $<.0001$ & 1 & Place \\
\hline$<.0001$ & $<.0001$ & 0.4551 & $<.0001$ & 0.3119 & 0.3153 & $<.0001$ & $<.0001$ & 19 & Genotype \\
\hline
\end{tabular}

Table V. Means of yield and stress tolerance indices in zinc stress and non stress conditions in wheat. GMP, STI, SSI, MP, TOL, EF, Y, and $\mathrm{Y}_{\mathrm{s}}$ are geometric mean productivity, stress tolerance index, stress susceptibility index, mean productivity, tolerance index, zinc-efficiency, grain yield under with added $\mathrm{Zn}$ treatment, and grain yield under without added $\mathrm{Zn}$ treatment, respectively.

\begin{tabular}{lcccccccc}
\hline Cultivar & $\mathbf{Y}_{\mathrm{p}}$ & $\mathbf{Y}_{\mathrm{s}}$ & $\mathbf{E F}$ & TOL & MP & SSI & STI & GMP \\
\hline Mahdavi & 7112 & 7664 & 110 & -552 & 7388 & -27.9 & 1.16 & 7352 \\
Bezostaya & 5957 & 5812 & 99.5 & 146 & 5884 & -21.8 & 0.734 & 5868 \\
Navid & 7928 & 7222 & 92 & 706 & 7575 & 119 & 1.20 & 7533 \\
Alamoot & 7566 & 7963 & 106 & -397 & 7764 & 58.6 & 1.30 & 7750 \\
Alvand & 8389 & 8575 & 102 & -186 & 8482 & 43 & 1.53 & 8470 \\
Zarin & 6973 & 7580 & 109 & -607 & 7277 & 90 & 1.13 & 7250 \\
MV-17 & 6647 & 6293 & 95.9 & 354 & 6470 & -135 & 0.900 & 6453 \\
Gaspard & 8397 & 7332 & 88 & 1034 & 7850 & -75.6 & 1.35 & 7814 \\
Gascogen & 6611 & 7131 & 108 & -520 & 6871 & -12.6 & 0.99 & 6853 \\
Sayson & 7703 & 7617 & 99.2 & 86.2 & 7660 & -50.5 & 1.27 & 7646 \\
Shahriar & 7585 & 8029 & 107 & -444 & 7807 & -55.0 & 1.31 & 7786 \\
Toos & 7712 & 8054 & 108 & -343 & 7883 & 66 & 1.34 & 7845 \\
Sabalan & 5500 & 5564 & 106 & -63 & 5532 & -60 & 0.651 \\
Roshan W.B.C & 7384 & 7552 & 102 & -168 & 7468 & 63 & 1.19 & 5497 \\
Shahi Cross & 6861 & 6410 & 94 & 451 & 6636 & 43.3 & 0.91 & 6580 \\
Shahpasand & 4838 & 3930 & 86 & 907 & 4384 & 30.5 & 0.392 \\
Omid & 4706 & 4673 & 106 & 32.7 & 4689 & 159 & 0.464 & 4303 \\
Azar2 & 6285 & 5182 & 90 & 1102 & 5734 & -2.9 & 0.674 \\
Sardari & 5710 & 4628 & 84 & 1083 & 5169 & 5.1 & 0.558 & 5653 \\
C-81-10 & 7149 & 7236 & 103 & -87 & 7192 & -128 & 1.12 & 5107 \\
LSD 5\% & 1272 & 812 & 21.5 & 1505 & 757 & 217 & 0.21 & 7163 \\
\hline
\end{tabular}

of STI are positively correlated to the grain yield produced both in the presence and absence of added $\mathrm{Zn}$. In addition, a very high and positive correlation was found between the STI and MP indicator while there was no significant relationship between the STI values and the amounts of Zn-efficiency calculated by the common formula $\left(\mathrm{Y}_{\mathrm{S}} / \mathrm{Y}_{\mathrm{p}}\right)$ used by several researchers. It has been previously mentioned that some $\mathrm{Zn}$ efficient genotypes have lower potential yields (Kalayci et al., 1999; Khoshgoftarmanesh et al., 2004a).

The same results were achieved where a three-dimensional plot among $\mathrm{Y}_{\mathrm{s}}$ (x-axis), $\mathrm{Y}_{\mathrm{p}}$ (y-axis) and STI (z-axis) was drawn based on grain yield of different bread wheat genotypes grown in severely Fe-deficient (stress condition) and Fefertilized soils (non-stress condition) (Fig. 3). Higher values of STI were related to Genotypes in Group A (genotypes with higher Fe efficiency and greater potential yield both in the presence and absence of added $\mathrm{Fe}$ ).

It seems using these stress indicators for separating proper micronutrient-efficient genotypes with higher potential yields would be useful in future studies. Additionally, developing new stress indicators through including other desirable crite- ria (i.e. concentrations of micronutrients as well as antinutrients and promoters in grains) is very useful in modern breeding programs. In this way, it would be possible to divide crop genotypes into different groups based on both qualitative and quantitative aspects.

\section{CONCLUSION}

We reviewed different possible approaches including soil and foliar fertilization, crop systems, application of soil amendments and organic sources, and genetic and agronomic biofortification to correct micronutrients deficiency and to increase their density in edible parts of plants.

Soil application of fertilizer is the easiest way to correct micronutrient deficiency; however, it is not always successful and sustainable due to agronomic and economic factors such as reduced availability of micronutrient element due to topsoil drying, subsoil constraints, disease interactions, and cost of fertilizer in developing countries. Foliar fertilization is more effective than soil application, but too expensive for 
Table VI. Coefficient of correlation between stress tolerance indices and yield in zinc stress and non stress conditions in wheat. GMP, STI, SSI, MP, TOL, EF, $\mathrm{Y}_{\mathrm{p}}$, and $\mathrm{Y}_{\mathrm{s}}$ are geometric mean productivity, stress tolerance index, stress susceptibility index, mean productivity, tolerance index, zinc-efficiency, grain yield under with added $\mathrm{Zn}$ treatment, and grain yield under without added $\mathrm{Zn}$ treatment, respectively.

\begin{tabular}{|c|c|c|c|c|c|c|c|c|}
\hline Trait & $\mathrm{Y}_{\mathrm{s}}$ & $Y_{p}$ & $\mathrm{EF}$ & TOL & MP & SSI & STI & GMP \\
\hline Ys & 1 & & & & & & & \\
\hline Yp & $0.91^{* *}$ & 1 & & & & & & \\
\hline $\mathrm{EF}$ & $0.16^{n s}$ & $0.55^{*}$ & 1 & & & & & \\
\hline MP & $-0.24^{n s}$ & $-0.63^{* *}$ & $-0.97^{* *}$ & 1 & & & & \\
\hline TOL & $0.97^{* *}$ & $0.98^{* *}$ & $0.38^{n s}$ & $-0.47^{*}$ & 1 & & & \\
\hline SSI & $-0.12^{n s}$ & $-0.06^{n s}$ & $0.09^{n s}$ & $-0.07^{n s}$ & $-0.08^{n s}$ & 1 & & \\
\hline STI & $0.96^{* *}$ & $0.97^{* *}$ & $0.38^{n s}$ & $-0.46^{*}$ & $0.99^{* *}$ & $-0.07^{n s}$ & 1 & \\
\hline GMP & $0.97^{* *}$ & $0.98^{* *}$ & $0.39^{n s}$ & $-0.47^{*}$ & $1.00^{* *}$ & $-0.08^{n s}$ & $0.99^{* *}$ & 1 \\
\hline
\end{tabular}

$*$ and $* *$ : significant at the $5 \%$ and $1 \%$ level of probability, respectively. ns: non significant.

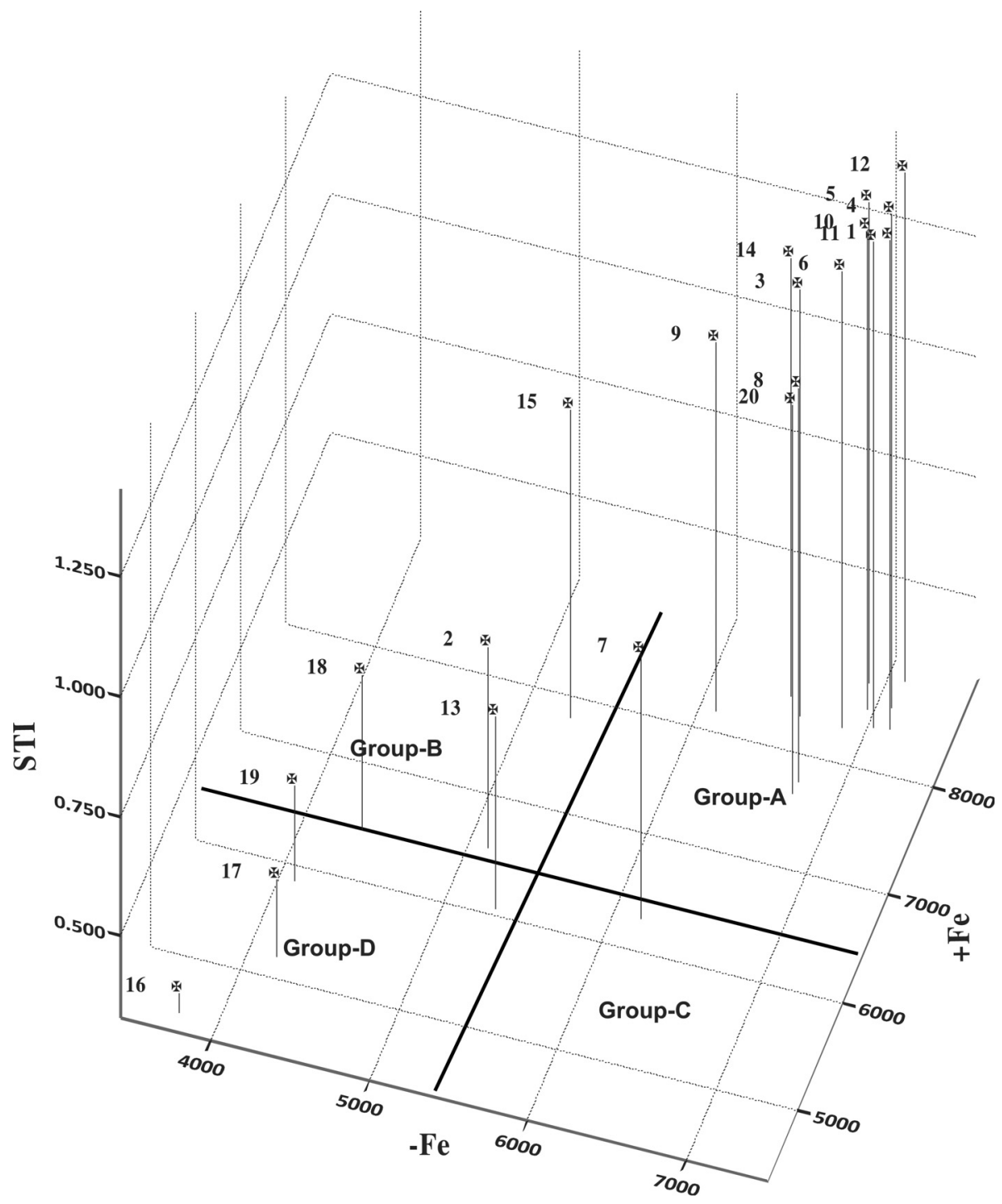

Figure 3. The 3-D plot among stress tolerance index (STI), -Fe and +Fe condition for different winter wheat cultivars. Group A, genotypes that are not affected by stress and produce the same in both stress and non-stress environments; Group B, genotypes that produce higher yield only in non-stress environments; Group C, genotypes with higher yield in stress condition and lower yield in non-stress environment; and Group D, genotypes with low yield in both stress and non-stress environments. Mahdavi (1), Bezostaya (2), Navid (3), Alamoot (4), Alvand (5), Zarin (6), MV-17 (7), Gaspard (8), Gascogen (9), Sayson (10), Shahriar (11), Toos (12), Sabalan (13), Roshan Winter Back Cross (14), Shahi Cross (15), Shahpasand (16), Omid (17), Azar2 (18), Sardari (19) and C-81-10 (20) (Khoshgoftarmanesh et al., 2007). 
resource-poor farmers. Seed priming is also an effective way to increase yield and is important for resource-poor farmers. It seems a reasonable intercropping or rotation system of nutrient efficient species will help to prevent or mitigate micronutrient deficiency of plants in agricultural practice.

Selecting and breeding staple food crops which are more efficient in the uptake of trace minerals from the soil and which load more trace minerals into their seeds combines benefits both for agricultural productivity and human nutrition. Plant crop yield under stress could be enhanced by selection or breeding of plants that have high micronutrient efficiency, and ability to interact effectively with environmental extremes. Cultivation of micronutrient-efficient crop genotypes may have important applications for increasing farm productivity in developing countries in an environmental-friendly way. This approach also holds great promise for making a significant, low-cost, and sustainable contribution to reducing micronutrient deficiencies in humans.

The combining of benefits for human nutrition and agricultural productivity, resulting from breeding improved staple food crops results in extremely high benefit-cost ratios for investments in agricultural research in this area. This approach would be more valuable and cost-effective by estimating the costs paid to heal micronutrient malnutrition in developing countries.

Despite beneficial effects of biofortified genotypes, we found the following major challenges in programs for selecting or breeding micronutrient-efficient genotypes: (1) The stability in response to nutrient efficiency in different environments and relationships between crop productivity, mineral concentrations, and other nutritional quality factors (e.g. concentrations of promoters and antinutrients) has less been considered. (2) There is no reliable indicator for identifying micronutrient-efficient genotypes with high grain yield. It seems that the stress tolerance index, STI, can be used to identify genotypes that produce high yields under both non-stress and stress environments. (3) In most cases, the crop yield has been considered as the main basis for separating micronutrient-efficient and inefficient genotypes while micronutrient-efficient genotypes may even contain lower micronutrient concentrations in their edible parts than micronutrient-inefficient genotypes. Therefore, combining crop productivity and grain quality aspects such as total content and bioavailability of nutrients in developing new micronutrient-efficient genotypes is necessary. (4) Breeding programs to improve grain micronutrient concentration should check to assure that a toxic metal such as $\mathrm{Cd}$ is not being increased along with micronutrients.

\section{REFERENCES}

Abedin M.J., Cotter-Howells J., Meharg A.A. (2002) Arsenic uptake and accumulation in rice (Oryza sativa L.) irrigated with contaminated water, Plant Soil 240, 311-319.

ACC/SCN (1992) Second Report on the World Nutrition Situation, Vol. I, Global and Regional Results, in: Garcia M., Mason J. (Eds.), pp. 180. ACC/SCN, United Nations, Geneva, Switzerland.
ACC/SCN (1997) United Nations Report on World Nutrition. The 3rd Report. Chapter 2: Micronutrients, pp. 19-52, ACC/SCN, United Nations, Geneva, Switzerland.

ACC/SCN (2000) Ending malnutrition by 2020: An agenda for change in the millennium. Commission Report, pp. 1-110, ACC/SCN, United Nations, Geneva, Switzerland.

Afyuni M., Khoshgoftarmanesh A.H., Dorostkar V., Moshiri R. (2007) Zinc and Cadmium content in fertilizers commonly used in Iran. International Conference of Zinc-Crops, May 24-28, Istanbul, Turkey.

Ahmed A., Anjum F.M., Rehman S.Ur., Randhava M.A., Farooq U. (2008) Bioavailability of calcium, iron and zinc fortified whole wheat flour Chapatti, Plant Food. Hum. Nutr. 63, 7-13.

Alam S.M. (1999) Nutrient uptake by plants under stress conditions, in: Pessarakli M. (Ed.), Handbook of plant and crops stress, Marcel Dekker, New York, pp. 285-313.

Alexandratos N. (1995) World Agriculture Towards 2010: An FAO Study, John Wiley and Sons, Chichester, West Sussex.

Allen L.H. (2000) Ending Hidden Hunger: the History of Micronutrient Deficiency Control. Background Analysis for the World BankUNICEF Nutrition Assessment Project World Bank.

Alvarez J.M., Gonzalez D. (2006) Zinc transformations in neutral soil and zinc efficiency in maize fertilization, J. Agr. Food Chem. 54, 9488-9495.

Alvey S., Bagayoko M., Neumann G., Buerkert A. (2001) Cereal/legume rotations affect chemical properties and biological activities in two West African soils, Plant Soil 231, 45-54.

Andersson A. (1983) Composted municipal refuse as fertilizer and soil conditioner. Effects on the contents of heavy metals in soil and plant, as compared to sewage sludge, manure and commercial fertilizers, in: Berglund S., Davis R.D., L'Hermite P. (Eds.), Utilization of Sewage Sludge on Land: Rates of Application and Long-Term Effects of Metals, D. Reidel Publ., Dordrecht, pp. 146-156.

Atta S.K., Mohammed S.A., van Cleemput O., Zayed A. (1996) Transformations of iron and manganese under controlled Eh, Eh$\mathrm{pH}$ conditions and additions of organic matter, Soil Technol. 9, 223-237.

Bagci S.A., Ekiz H., Yilmaz A., Cakmak I. (2007) Effects of zinc deficiency and drought on grain yield of field-grown wheat cultivars in Central Anatolia, J. Agron. Crop Sci. 193, 198-206.

Baligar V.C., Duncan R.R., Fageria N.K. (1990) Soil-plant interactions on nutrient use efficiency in plants. An overview, in: Baligar V.C., Duncan R.R. (Eds.), Crops as enhancers of nutrient use, Academic Press, San Diego, California, pp. 351-373.

Baligar V.C., Fageria N.K., He Z.L. (2001) Nutrient use efficiency in plants, Commun. Soil Sci. Plant Anal. 32, 921-950.

Barker A.V., Pilbeam D.J. (2007) Handbook of Plant Nutrition, Taylor and Francis Group Press, Boca Raton, FL.

Barnes J.P., Putnam A.R. (1986) Evidence for allelopathy by residues and aqueous extracts of rye (Secale cereale L.), Weed Sci. 34, 384-390.

Barrier-Guillot B., Casado P., Maupetit P., Jondreville C., Gatel F. (1996) Wheat phosphorus availability. In vitro Study; Factors affecting endogenous phytasic activity and phytic phosphorus content, J. Sci. Food Agr. 70, 62-68.

Bhowmik P.C., Doll J.D. (1984) Allelopathic effects of annual weed residues on growth and nutrient uptake of corn and soybeans, Agron. J. 76, 383-388.

Black R. (2003) Micronutrient deficiency — an underlying cause for morbidity and mortality, B. World Health Organ. 2003, 81-79. 
Blair G. (1993) Nutrient efficiency-what do we really mean, in: Randall P.J., Delhaize E., Richards R.A., Munns R. (Eds.), Genetic aspects of mineral nutrition, Kluwer Academic Publishers, Dordrecht, The Netherlands, pp. 205-213.

Blum A. (1988) Plant Breeding for Stress environments, CRC Press, Florida, p. 212

Borlaug N.E., Dowswell C.R. (1993) Fertilizer: To nourish infertile soil that feeds a fertile population that crowds a fragile world, Fertil. News 387, 11-20.

Bouis H. (1996) Enrichment of food staples through plant breeding: A new strategy for fighting micronutrient malnutrition, Nutr. Rev. 54, $131-137$.

Brabin B.J., Coulter J.B.S. (2003) Nutrition-associated disease, in: Cook G.C., Zumla A.I. (Eds.), Manson's tropical diseases, Saunders, London, pp. 561-580.

Brady N.C., Weil R.R. (2002) The nature and properties of soils, 13th edition, Prentice Hall, Upper Saddle River, New Jersey.

Brennan R.F. (1992) Effect of zinc fertilizer on take-all and grain yield of wheat grown on zinc deficient soils of the esperance region, West. Aust. Fer. Res. 31, 215-216.

Brennan R.F., Bolland M.D.A. (2006) Residual values of soil-applied zinc fertiliser for early vegetative growth of six crop species, Aust. J. Exp. Agr. 46, 1341-1347.

Broadley M.R., White P.J., Bryson R.J., Meacham M.C., Bowen H.C., Johnson S.E., Hawkesford M.J., McGrath S.P., Zhao F.J., Breward N., Harriman M., Tucker M. (2006) Biofortification of UK food crops with selenium, Proc. Nutr. Soc. 65, 169-181.

Bronick C.J., Lal R. (2005) Manuring and rotation effects on soil organic carbon concentration for different aggregate size fractions on two soils in northeastern Ohio, USA, Soil Till. Res. 81, 239-252.

Brown L.R. (1997) Facing the challenge of food scarcity: Can we raise grain yields fast enough? in: Ando T., Fujita K., Mae T., Matsumoto H., Mori S., Sekiya J. (Eds.), Plant nutrition for sustainable food production and environment, Kluwer Academic Publishers, Dordrecht, The Netherlands, pp. 15-24.

Buso G.S.C., Bliss F.A. (1988) Variability among lettuce cultivars grown at two levels of available phosphorus, Plant Soil 111, 67-73.

Buyckx M. (1993) The international community's commitment to combating micronutrient deficiencies, Food Nutr. Agr. 7, 2-7.

Byrnes B.H., Bumb B.L. (1998) Population growth, food production and nutrient requirements, in: Rengel Z. (Ed.), Journal of Crop Production. The Haworth Press, New York, pp. 1-27.

Cai S., Yue L., Jin T., Nordberg G. (1998) Renal dysfunction from cadmium contamination of irrigation water: Dose-response analysis in a Chinese population, B. World Health Organ. 76, 153-159.

Cakmak I. (2002) Plant nutrition research: Priorities to meet human needs for food in sustainable ways, Plant Soil 247, 3-24.

Cakmak I. (2008) Enrichment of cereal grains with zinc: Agronomic or genetic biofortification? Plant Soil 302, 1-17.

Cakmak I., Marschner H. (1986) Mechanism of phosphate induced zinc deficiency in cotton. I. Zinc deficiency-enhanced uptake rate of phosphorus, Physiol. Plant 68, 483-490.

Cakmak I., Sari N., Marschner H., Ekiz H., Kalayci M., Yilmaz A., Braun H.J. (1996) Phytosiderophore release in bread and durum wheat genotypes differing in zinc efficiency, Plant Soil 180, 183-189.

Cakmak I., Ekiz H., Yilmaz A., Torun B., Koleli N., Gultekin I., Alkan A., Eker S. (1997a) Differential response of rye, triticale, bread and durum wheats to zinc deficiency in calcareous soils, Plant Soil 188 $1-10$.
Cakmak I., Derici R., Torun B., Tolay I., Braun H.J., Schlegel R. (1997b) Role of rye chromosomes in improvement of zinc efficiency in wheat and triticale, Plant Soil 196, 249-253.

Cakmak I., Torun B., Erenoglu B., Oztürk L., Marschner H., Kalayci M., Ekiz H., Yilmaz A. (1998) Morphological and physiological differences in cereals in response to zinc deficiency, Euphytica 100, 349-357.

Caradus J.R. (1990) Mechanisms improving nutrient use by crop and herbage legumes, in: Baligar V.C., Duncan R.R. (Eds.), Crops as enhancers of nutrient use, San Diego, Academic Press, California, pp. 253-311.

Carr A.J.H., Stoddart J.L. (1963) The ameliorating effect of zinc on symptoms of phyllody virus in white clover, Ann. Appl. Biol. 51, 259268.

Cary E.E., Norvell W.A., Grunes D.L., Welch R.M., Reid W.S. (1994) Iron and Manganese Accumulation by the brz Pea Mutant Grown in Soils, Agron. J. 86, 938-41.

Chaney R.L., Ryan J.A. (1993) Heavy metals and toxic organic pollutants in MSW-composts: Research results on phytoavailability, bioavailability, etc., in: Hoitink H.A.J., Keener H.M. (Eds.), Science and Engineering of Composting: Design, Environmental, Microbiological and Utilization Aspects, Ohio State Univ., Columbus, OH, pp. 451-506.

Chaney R.L., Reeves P.G., Ryan J.A., Simmons R.W., Welch R.M., Angle J.S. (2004) An improved understanding of soil Cd risk to humans and low cost methods to remediate soil Cd risks, BioMetals 17, $549-553$.

Christian P., West K.P. Jr. (1998) Interactions between zinc vitamin A: An update, Am. J. Clin. Nutr. 68 (Suppl.), S435-S441.

Clark R.B. (1990) Physiology of cereals for mineral nutrient uptake, use, and efficiency, in: Baligar V.C., Duncan R.R. (Eds.), Crops as enhancers of nutrient use, Academic Press, San Diego, California, pp. 131-209.

Cobiac L., Baghurst K. (1993) Iron status and dietary iron intakes of Australians, CSIRO Astralia, Adelaide, SA.

Combs G.F. Jr., Welch R.M. (1998) Creating Healful Food Systems: Linking Agriculture to Human Needs, Cornell International Institute for Food, Agriculture and Development, Cornell University, Ithaca, NY, pp. 1-34.

Combs G.F. Jr., Welch R.M., Duxbury J.M., Uphoff N.T., Nesheim M.C. (1996) Food-Based Approaches to Preventing Micronutrient Malnutrition: an International Research Agenda. Cornell International Institute for Food, Agriculture, and Development, Cornell University, Ithaca, NY, pp. 1-68.

Cottenie A., Kang B.T., Kieken, S.L., Sajjapongse A. (1981) Micronutrient status, in: Greenland D.J. (Ed.), Characterization of Soils, Clarendon, Oxford, UK, pp. 149-163.

DellaPenna D. (1999) Nutritional genomics: manipulating plant micronutrients to improve human health, Science 285, 375-379.

Diekow J.J., Mielniczuk J., Knicker H., Bayer C., Dick D.P., Kögel-Knabner I. (2005) Soil C and N stocks as affected by cropping systems and nitrogen fertilisation in a southern Brazil Acrisol managed under no-tillage for 17 years, Soil Till. Res. 81, 87-95.

Donald C.M., Prescot J.A. (1975) Trace elements in Australian crop and pasture production, in: Nicholas D.J.D., Egan R.A. (Eds.), Trace Elements in Soil-Plant-Animal Systems, Academic Press, New York, pp. 7-37.

Drakakaki G., Marcel S., Glahn R.P., Lund E.K., Pariagh S., Fischer F., Christou P., Stoger E. (2005) Endosperm-specific co-expression of recombinant soybean ferritin and Aspergillus phytase in maize results in significant increases in the levels of bioavailable iron, Plant Mol. Biol. 59, 869-880. 
Eghball B., Ginting D., Gilley J.E. (2004) Residual effects of manure and compost applications on corn production and soil properties, Agron. J. 96, 442-447.

Erdal I., Yilmaz A., Taban S., Eker S., Torun B., Cakmak I. (2002) Phytic acid and phosphorus concentrations in seeds of wheat cultivars grown with and without zinc fertilization, J. Plant Nutr. 25, $113-127$.

Fageria N.K. (2000a) Adequate and toxic levels of boron for rice, common bean, corn, soybean and wheat production in Cerrado soil, $\mathrm{R}$. Bras. Eng. Agr. Ambiental. 4, 57-62.

Fageria N.K. (2000b) Adequate and toxic levels of zinc for rice, common bean, corn, soybean and wheat production in Cerrado soil, R. Bras. Eng. Agr. Ambiental. 4, 390-395.

Fageria N.K., Baligar V.C. (2003) Methodology for evaluation of lowland rice genotypes for nitrogen use efficiency, J. Plant Nutr. 26, 13151333 .

Fageria N.K., Barbosa Filho M.P. (2001) Nitrogen use efficiency in lowland rice genotypes, Commun. Soil Sci. Plan. 32, 2079-2089.

Fageria N.K., Baligar V.C., Clark R.B. (2002) Micronutrients in crop production, Adv. Agron. 77, 185-268.

Fageria N.K., Baligar V.C., Li Y.C. (2008) The role of nutrient efficient plants in improving crop yields in the twenty first Century, J. Plant Nutr. 31, 1121-1157.

FAO (Food and Agriculture Organization) (1999) Yearbook of Fertilizers, Food and Agriculture Organization of the United Nations, Rome, Italy.

Fernandez G.C.J. (1991) Analysis of cultivar $\times$ environment interaction by stability estimates, HortScience 26, 947-950.

Fernandez G.C.J., Chen H.K., Miller J.C. Jr. (1989) Adaptation and environmental sensitivity of mungben genotypes evaluated in the International Mungbean Nursery, Euphytica 41, 253-261.

Fischer R.A., Maurer R. (1978) Drought resistance in spring wheat cultivars. I. Grain yield responses, Aust. J. Agr. Res. 29, 897-912.

Fleming G.A., Mordenti A. (1991) The Production of Animal Wastes, European Conference on Environment and Agriculture, Stock Farming in Europe, Mantua, Italy.

Food and Agriculture Organization of the United Nations (2004) Undernourishment around the world, in: The state of food insecurity in the world 2004, The Organization, Rome.

Foy C.D. (1984) Physiological effects of hydrogen, aluminum and manganese toxicities in acid soils, in: Adams F. (Ed.), Soil Acidity and Liming, 2nd ed., American Society of Agronomy, Madison, WI, pp. 57-97.

Foy C.D. (1992) Soil chemical factors limiting plant growth, Limitations to Plant Root Growth, in: Hatfield J.L., Stewart B.A. (Eds.), Adv. Soil Sci. 19, 97-149.

Frey K.J. (1964) Adaption reaction of oat strains selected under stress and non-stress environmental condition, Crop Sci. 4, 55-58.

Frossard E., Bucher M., Mächler F., Mozafar A., Hurrell R. (2000) Potential for increasing the content and bioavailability of $\mathrm{Fe}, \mathrm{Zn}$ and Ca in plants for human nutrition, J. Sci. Food Agr. 80, 861-879.

Galrão E.Z. (1999) Methods of copper application and evaluation of its availability for soybean grown on a Cerrado red-yellow latosol, R. Bras. Ci. Solo. 23, 265-272.

Gao M., Che F.C., Wei C.F., Xie D.T., Yang J.H. (2000) Effect of longterm application of manures on forms of $\mathrm{Fe}, \mathrm{Mn}, \mathrm{Cu}$ and $\mathrm{Zn}$ in purple paddy soil, Plant Nutr. Fertil. Sci. 6, 11-17.

Garcia-Casal M.N., Layrisse M., Solano L., Baron M.A., Arguello F., LIovera D., Ramirez J., Leets I., Tropper E. (1998) Vitamin A and beta carotene can improve nonheme iron absorption from rice, wheat and corn by humans, J. Nutr. 128, 646-650.

Gargari B.P., Mahboob S., Razavieh S.V. (2007) Content of phytic acid and its mole ratio to zinc in flour and breads consumed in Tabriz, Iran, Food Chem. 100, 1115-1119.

Gerloff, Gabelman (1983) Genetic basis of inorganic plant nutrition, in: Lauchli A., Bieleski R.L. (Eds.), Inorganic Plant Nutrition. Encyclopedia and Plant Physiology New Series, Springer Verlag, New York, NY, Vol. 15B, pp. 453-480.

Gibson R.S. (1994) Zinc nutrition in developing countries, Nutr. Res. Rev. 7, 151-173.

Gibson R.S. (2006) Zinc: the missing link in combating micronutrient malnutrition in developing countries, Proc. Nutr. Soc. 65, 51-60.

Gibson R.S., Sazawal S., Peerson J.M. (2003) Design and quality control issues related to dietary assessment, randomized clinical trials and meta-analysis of field-based studies in developing countries, J. Nutr. 133 (5 Suppl. 1), 1569s-1573s.

Gibson R.S., Hess S.Y., Hotz C., Brown. K.H. (2008) Indicators of zinc status at the population level: a review of the evidence, Brit. J. Nutr. 99 (Suppl. 3), S14-S23.

Glass A.D.M. (1989) Physiological mechanisms involved with genotypic differences in ion adsorption and utilization, HortScience 24, 559564.

Godwin D.C., Blair G.J. (1991) Phosphorus efficiency in pasture species. V. A comparison of white clover accessions, Aust. J. Agr. Res. 42, $531-540$.

Gonzalez D., Obrador A., Alvarez J.M. (2007) Behavior of zinc from six organic fertilizers applied to a navy bean crop grown in a calcareous soil, J. Agr. Food Chem. 55, 7084-7092.

Goto F., Yoshihara T., Shigemoto N., Toki S., Takaiwa F. (1999) Iron fortification of rice seed by the soybean ferritin gene, Nat. Biotechnol. $17,282-286$.

Goto K., Tanimoto Y., Tamura T., Mochida K., Arai D., Asahara M., Suzuki M., Tanaka H., Inagaki K. (2002) Identification of thermoacidophilic bacteria and a new Alicyclobacillus genomic species isolated from acidic environments in Japan, Extremophiles 6, 333340.

Gourley C.J.P., Allan D.L., Russelle M.P. (1994) Plant nutrient efficiency: A comparison of definitions and suggested improvement, Plant Soil $158,29-37$.

Graham R.D. (1984) Breeding for nutritional characteristics in cereals, in: Tinker P.B., Lauchi A. (Eds.), Advances in plant nutrition, Vol. 1, Praeger Publisher, New York, pp. 57-102.

Graham R.D., Webb M.J. (1991) Micronutirents and disease resistance and tolerance in plants, in: Mortvadt J.J., Cox F.R., Shuman L.M., Welch R.M. (Eds.), Micronutrients in Agriculture, 2nd ed., Soil Scienc Society American Book series No. 4, Madison, WI, pp. 329370.

Graham R.D., Rengel Z. (1993) Genotypic variation in zinc uptake and utilization by plants, in: Robson A.D. (Ed.), Zinc in Soils and Plants, Kluwer Academic Publishers, Dordrecht, pp. 107-118.

Graham R.D., Welch R.M. (1996) Breeding for staple-food crops with high micronutrient density. Agricultural Strategies for Micronutrients. Working Paper No. 3, International Food Policy Research Institute, Washington, DC.

Graham R.D., Ascher J.S., Hynes S.C. (1992) Selecting zinc efficient cereal genotypes for soils of low zinc status, Plant Soil 146, 241-250.

Graham R.D., Senadhira D., Beebe S.E., Iglesias C., Ortiz-Monasterio I. (1999) Breeding for micronutrients density in edible portions of staple food crops: conventional approaches, Field Crop. Res. 60, $57-80$. 
Graham R.D., Humphries J.M., Kitchen J.L. (2000) Nutritionally enhanced cereals: A sustainable foundation for a balanced diet, Asia Pac. J. Clin. Nutr. 9 (Suppl.), S91-S96.

Graham R.D., Welch R.M., Bouis H.E. (2001) Addressing micronutrient malnutrition through enhancing the nutritional quality of staple foods: Principles, perspectives and knowledge gaps, Adv. Agron. 70, 77-142.

Grant C.A., Clarke J.M., Duguid S., Chaney R.L. (2008) Selection and breeding of plant cultivars to minimize cadmium accumulation, Sci. Total Environ. 390, 301-310.

Grewal H.S., Graham R.D. (1999) Residual effects of subsoil zinc and oilseed rape genotype on the grain yield and distribution of zinc in wheat, Plant Soil 207, 29-36.

Gunes A., Inal A., Adak M.S., Alpaslan M., Bagci E.G., Erol T., Pilbeam D.G. (2007) Mineral nutrition of wheat, chickpea and lentil as affected by mixed cropping and soil moisture, Nutr. Cycl. Agroecosys. 78, 83-96.

Hacisalihoglu G. (2002) Physiological and biochemical mechanisms underlying zinc efficiency in monocot and dicot crop plants, $\mathrm{PhD}$ Thesis, Cornell University, Ithaca, New York, USA.

Harris D., Rashid A., Miraj Gh., Arif M., Yunas M. (2008) 'On-farm' seed priming with zinc in chickpea and wheat in Pakistan, Plant Soil 306, 3-10.

Harris D., Rashid A., Miraj Gh., Arif M., Shah H. (2007) 'On-farm' seed priming with zinc in chickpea and wheat in Pakistan, Plant Soil 306, 3-10.

Hart J.J., Welch R.M., Norvell W.A., Kochian L.V. (2002) Transport interactions between cadmium and zinc in roots of bread and durum wheat seedlings, Physiol. Plantarum 116, 73-78.

Hill C.H., Matrone G. (1970) Chemical parameters in the study of in vivo and in vitro interactions of transition elements, Fed Proc. 29, 1474 1481.

Hodges R.E., Saurberlich H.E., Canham J.E., Wallace D.L., Rucker R.B., Mejia L.A., Mohanram M. (1978) Hematopoietic studies in vitamin A deficiency, Am. J. Clin. Nutr. 31, 876-885.

House W.A. (1999) Trace element bioavailability as exemplified by iron and zinc, Field Crop. Res. 60, 115-141.

Huber D.M., Abney, T.S. (1986) Soybean allelopathy and subsequent cropping, J. Agron. Crop Sci. 157, 73-78.

Hylander L.D. (1995) Effects of lime, phosphorus, manganese, copper and zinc on plant mineral composition, yield of barley, and level of extractable nutrients for an acid Swedish mineral soil, Commun. Soil Sci. Plan. 26, 2913-2928.

International Zinc Nutrition Consultative Group (IZiNCG) (2004) Assessment of the risk of zinc deficiency in populations and options for its control, in: Hotz C., Brown K.H. (Eds.), Food and nutrition bulletin, Vol. 25, No. 1, Suppl. 2, pp. S113-S118.

Isfan D. (1993) Genotypic variability for physiological efficiency index of nitrogen in oats, Plant Soil 154, 53-59.

Kalayci M., Torun B., Eker S., Aydin M., Ozturk L., Cakmak I. (1999) Grain yield, zinc efficiency and zinc concentration of wheat cultivars grown in a zinc-deficient calcareous soil in field and greenhouse, Field Crop. Res. 63, 87-98.

Kang Y.L. (1988) Effects of organic matter and its anaerobic decomposition products on the growth and zinc uptake by Oryza sativa, Disser. Abst. Int. B (Sci., Eng.) 49, 953B.

Kannenberg L.W., Falk D.E. (1995) Models for activation of plant genetic resources for crop breeding programs, Can. J. Plant Sci. 75, 45-53.

Katyal J.C. (1977) Influence of organic matter on the chemical and electrochemical properties of some flooded soils, Soil Biol. Biochem. 9, 259-266.
Katyal J.C., Vlek P.L.G. (1985) Micronutrient problems in tropical Asia, Fert. Res. 7, 69-94.

Keller A., Schulin R. (2003) Modelling heavy metal and phosphorus balances for farming systems, Nutr. Cycl. Agroecosys. 66, 271-284.

Khoshgoftarmanesh A.H., M. Kalbasi (2002) Effect of Municipal waste Leachate on soil properties and growth and yield of rice, Commun. Soil Sci. Plan. 33, 2011-2020.

Khoshgoftar, A.H., HajiMozaffari E. (2006) Approaches to enhance iron concentration in wheat grain produced in Qom province. Iran. 2nd Central Asian Cereals Conference, June 13-16, 2006, Cholpon-Ata, Issyk Kul Lake, Kyrgyz Republic.

Khoshgoftar A.H., Chaney R.L. (2007) Preceding crop affects grain cadmium and zinc of wheat grown in saline soils of central Iran, J. Environ. Qual. 36, 1132-1136.

Khoshgoftarmanesh A.H., Shariatmadari H., Kalbasi M., Karimian N. (2004a) Zinc efficiency of wheat cultivars grown on a saline calcareous soil, J. Plant Nutr. 27, 1953-1962.

Khoshgoftar A.H., Shariatmadari H., Karimian N., Kalbasi M., van der Zee S.E.A.T.M., Parker D.R. (2004b) Salinity and Zn application effects on phytoavailability of $\mathrm{Cd}$ and $\mathrm{Zn}$, Soil Sci. Soc. Am. J. 68, 1885-1889.

Khoshgoftar A.H., Shariatmadari H., Karimian N., and van der Zee S.E.A.T.M. (2006a) Cadmium and zinc in saline soil solutions and their concentrations in wheat, Soil Sci. Soc. Am. J. 70, 582-589.

Khoshgoftar A.H., Shariatmadari H., Karimian N. (2006b) Responses of wheat genotypes to zinc fertilization under saline soil conditions, J. Plant Nutr. 27, 1-14.

Khoshgoftarmanesh A.H., Sharifi H.R., Mirzapour M.H., Schulin R. (2007) Plant genotype and Zn fertilization effects on nutritional quality of wheat grain produced in saline soils. 9th International Conference of the Biochemistry of Trace Elements (ICOBTE), July 2007, Beijing, China.

Kochian L.V. (1995) Cellular mechanisms of aluminum toxicity and resistance in plants, Annu. Rev. Plant Phys. 46, 237-260.

Leon L.A., Lopez A.S., Vlek P.L.G. (1985) Micronutrient problems in tropical Latin America, Fert. Res. 7, 95-129.

Liu X.J., Liao X.Y., Zhang Y.Z., Huang Y.X. (2002) Effects of ricebased cropping system on the distribution of manganese in the profile of paddy soil derived from red earth, Acta Ecol. Sin. 22, 1440-1445.

Loneragen J.P. (1997) Plant nutrition in 20th and perspectives for the 21st century, Plant Soil 196, 163-174.

Lopes A.S., Cox F.R. (1977) A survey of the fertility status of surface soils under 'Cerrado' vegetation in Brazil, Soil Sci. Soc. Am. J. 41, $742-747$.

Lucca P., Hurrell R.F., Potrykus I. (2001) Genetic engineering approaches to improve the bioavailability and the level of iron in rice grains, Theor. Appl. Genet. 102, 392-397.

Marschner H. (1995) Mineral Nutrition of Higher Plants, 2nd ed., Academic Press, London.

Mason J.B., Garcia M. (1993) Micronutrient deficiency - the global situation, SCN News 9, 11-16.

Martens D.C., Westerman D.T. (1991) Fertilizer applications for correcting micronutrient deficiencies, in: Mortvedt J.J., Cox F.R., Shuman L.M., Welch R.M. (Eds.), Micronutrients in Agriculture, 2nd ed., SSSA Book Series 4, SSSA, Madison, WI, pp. 549-592.

Martens D.C., Lindsay W.L. (1990) Testing soils for copper, iron, manganese, and zinc, in: Westerman R.L. (Ed.), Soil Testing and Plant Analysis, Soil Science Society of America, Madison, WI, pp. 229273. 
Mayer J.E., Pfeiffer W.H., Beyer P. (2008) Biofortified crops to alleviate micronutrient malnutrition, Curr. Opin. Plant Biol. 11, 166-170.

McGuire J. (1993) Addressing micronutrient malnutrition, SCN News 9, $1-10$.

McIntyre B.D., Bouldin D.R., Urey G.H., Kizito F. (2001) Modeling cropping strategies to improve human nutrition in Uganda, Agr. Syst. 67, 105-120.

McLaughlin M.J., Parker D.R., Clarke J.M. (1999) Metals and micronutrients - Food safety issues, Field Crop. Res. 60, 143-163.

Meharg A.A. (2004) Arsenic in rice - understanding a new disaster for South-East Asia, Trends Plant Sci. 9, 415-417.

Menzi H., Kessler J. (1998) Heavy metal content of manures in Switzerland, in: Proceedings of the Eighth International Conference of the FAO Network on Recycling of Agricultural, Municipal and Industrial Residues in Agriculture (in press).

Miller D., Waissman N., Melton B., Currier C., McCaslin B. (1987) Selection for increased phosphorus in alfalfa and effects on other characteristics, Crop Sci. 27, 22-26.

Mitchell C.C., Entry J.A. (1998) Soil C, N and crop yields in Alabama's long-term 'old rotation' cotton experiment, Soil Till. Res. 47, 331338 .

Mortvedt J.J. (1985) Plant uptake of heavy metals in zinc fertilizers made from industrial by-products, J. Environ. Qual. 14, 424-427.

Mortvedt J.J. (1994) Needs for controlled-availability micronutrient fertilizers, Fert. Res. 38, 213-221.

Mortvedt, J.J. (1996) Heavy metal contaminants in inorganic and organic fertilizers, Fert. Res. 43, 55-61.

Murray C.J.L., Lopez A.D. (1997) Global mortality, disability, and the contribution of risk factors: Global Burden of Disease Study, Lancet $349,1436-42$.

Nable R.O., Webb M.J. (1993) Further evidence that zinc is required throughout the root zone for optimal growth and development, Plant Soil 150, 247-253.

Neidecker-Gonzales O., Nestel P., Bouis H. (2007) Estimating the global costs of vitamin A capsule supplementation: A review of the literature, Food Nutr. Bull. 28, 307-316.

Nicholson F.A., Chambers B.J., Williams J.R., Unwin R.J. (1999) Heavy metal contents of livestock feeds and animal manures in England and Wales, Bioresource Technol. 70, 23-31.

Nicklas T.A. (1995) Dietary studies of children: the Bogalu Heart Study experience, J. Am. Diet. Assoc. 95, 1127-1133.

Nogawa K., Kobayashi E., Okubo Y., Suwazono Y. (2004) Environmental cadmium exposure, adverse effects and preventive measures in Japan, BioMetals 17, 581-587.

Novack B., Schwyzer I., Schulin R. (2008) Uptake of Zn and Fe by Wheat (Triticum aestivum var. Greina) and Transfer to the Grains in the Presence of Chelating Agents (Ethylenediaminedisuccinic Acid and Ethylenediaminetetraacetic Acid), Agr. Food Chem. 56, 46434649.

O'Dell B.L., de Boland A.R., Koirtyohann S.R. (1972) Distribution of phytate and nutritionally important elements among the morphological components of cereal grains, J. Agr. Food Chem. 20, 718 721.

Pareek S., Pareek S. (1999) Effect of macro-and micro-nutrients on charcoal rot disease development of maize induced by Macrophominea phaseolina, Ann. Agr. Res. 20, 129-131.

Pessarakli M. (ed.) (1999) Handbook of plant and crops stress, Marcel Dekker, New York.
Pinstrup-Andersen P. (1999) Selected aspects of the future global food situation, in: 25th International Fertilizer Industry Association Enlarged Council Meeting, Rome, Italy.

Prasad B. (1999) Conjoint use of fertilizers with organics, crop residues and green manuring for their efficient use in sustainable crop production, Fert. News 44, 67-73.

Prasad B., Sinha M.K. (1981) The relative efficiency of zinc carriers on growth and zinc nutrition of corn, Plant Soil 62, 45-52.

Prasad B., Sinha S.K. (1995a) Effect of recycling of crop residues and organic manure on capacity factor and diffusion rate of zinc in calcareous soil, J. Nucl. Agr. Biol. 24, 185-188.

Prasad B., Sinha S.K. (1995b) Nutrient recycling through crop residues management for sustainable rice and wheat production in calcareous soil, Fert. News 40, 15-2325.

Raboy V., Noaman M.W., Taylor G.A., Pickett S.G. (1991) Grain phytic acid and protein are highly correlated in winter wheat, Crop Sci. 31, 631-635.

Raj H., Gupta V.K. (1986) Influence of organic manures and zinc on wheat yield and $\mathrm{Zn}$ concentration in wheat, Agr. Wastes 16, 255263.

Ramalingaswami V. (1995) New global perspectives on overcoming malnutrition, Am. J. Clin. Nutr. 61, 259-263.

Reeves P.G. Chaney R.L. (2008) Bioavailability as an issue in risk assessment and management of food cadmium: A review, Sci. Total Environ. 398, 13-19.

Rengel Z. (2001) Genotypic differences in micronutrient use efficiency in crops, Commun. Soil Sci. Plan. 32, 1163-1186.

Rengel Z., Graham R.D. (1995) Importance of seed Zn content for wheat growth on Zn-deficient soil. 2. Grain yield, Plant Soil 173, 267-274.

Rengel Z., Batten G.G., Crowley D.E. (1999) Agronomic approaches for improving the micronutrient density in edible portions of field crops, Field Crop. Res. 60, 27-40.

Reuter D.J., Alston A.M., McFarland J.D. (1988) Occurrence and correction of manganese deficiency in plants, in: Graham R.D., Hannan R.J., Uren N.C. (Eds.), Manganese in Soils and Plants, Kluwer Academic, Dordrecht, The Netherlands, pp. 205-224.

Rice E.L. (1984) Allelopathy, 2nd ed, Academic Press, Orlando, FL, $422 \mathrm{p}$.

Rose S.J., Burnside O.C., Specht J.E., Swisher B.A. (1984) Competition and allelopathy between soybeans and weeds, Agron. J. 76, 523528.

Rosegrant M.W., Leach N., Gerpacio R.V. (1999) Alternative future for world cereal and meat consumption, Proc. Nutr. Soc. 58, 219- 234.

Rosegrant M.W., Paisner M.S., Meijer S., Witcover J. (2001) 2020 Global Food Outlook; Trends, Alternatives, and Choices. A 2020 Vision for Food, Agriculture, and the Environment Initiative, International Food Policy Research Institute, Washington, DC.

Rosielle A.A., Hamblin J. (1981) Theoretical aspects of selection for yield in stress and non-stress environments, Crop Sci. 21, 943-946.

Sanghvi T.G. (1996) Economic Rationale for Investing in Micronutrient Programs. A Policy Brief Based on New Analyses. Office of Nutrition, Bureau for Research and Development, United States Agency for International Development, Washington, DC.

Sauerbeck D.R., Helal H.M. (1990) Factors affecting the nutrient efficiency in plants, in: El Balsam N., Dambroth M., Loughman B.C. (Eds.), Genetic Aspects of Plant Mineral Nutrition, Kluwer Academic Publisher, Dordrecht the Netherlands, pp. 11-17.

Schulin R., Khoshgoftarmanesh A., Afyuni M., Nowack B., Frossard E. (2009) Effect of soil management on zinc uptake and its bioavailability in plants, in: Banuelos G.S., Lin Z. (Eds.), Development and 
uses of biofortified agricultural products, CRC Press, Boca Raton, FL.

Shaver T.M., Westfall D.G., Ronaghi M. (2007) Zinc fertilizer solubility and its effects on zinc bioavailability over time, J. Plant Nutr. 30, $123-133$.

Siddiqi M.Y., Glass A.D. (1981) Utilization Index: A modified approach to the estimation and comparison of nutrient utilization efficiency in plants, J. Plant Nutr. 4, 289-302.

Sillanpaa M. (1982) Micronutrients and Nutrient Status of Soils: A Global Study; Food and Agriculture Organization: Rome, FAO Soil Bull. No. 48 .

Sillanpaa M., Vlek P.L.G. (1985) Micronutrients and the agroecology of tropical and Mediterranean regions, Fert. Res. 7, 151-168.

Sims J.T., Wolf D.C. (1994) Poultry waste management: Agricultural and Environmental issues, Adv. Agron. 52, 2-72.

Singh G., Abrol I.P., Cheema S.S. (1989) Effects of gypsum application on mesquite (Prosopisjulitlora) and soil properties in an abandoned sodic soil, Forest. Ecol. Manag. 29, 1-14.

Singh B., Natesan S.K.A., Singh B.K. Usha K. (2005) Improving zinc efficiency of cereals under zinc deficiency, Curr. Sci. 88, 36-44.

Soil Science Society of America (1997) Glossary of soil science terms, Soil Science Society of America, Madison, Wisconsin.

Solomons N.W., Russell R.M. (1980) The interaction of vitamin A and zinc: Implications for human nutrition, Am. J. Clin. Nutr. 33, 20312040.

Stein A.J. (2006) Micronutrient Malnutrition and the Impact of Modern Plant Breeding on Public Health in India: How Cost-effective is Biofortification? Cuvillier Verlag.

Stein A.J., Nestel P., Meenakshi J.V., Qaim M., Sachdev H.P., Bhutta Z.A. (2007) Plant breeding to control zinc deficiency in India: how costeffective is biofortification? Public Health Nutr. 10, 492-501.

Stevenson F.J. (1991) Organic matter-micronutrient reaction in soil, in: Mortvedt J.J. et al. (Eds.), Micronutrients in Agriculture, Soil Sci. Soc. Am., Madison, WI, pp. 145-186.

Stevenson F.J. (1994) Humus chemistry; Genesis composition. Reaction, Wiley New York, p. 496.

Stewart W.M., Dibb D.W., Johnston A.E., Smyth T.J. (2005) The contribution of commercial fertilizer nutrients to food production, Agron. J. 97, 1-6.

Streeter J.G. (2001) Simple partial purification of D-pinitol from soybean leaves, Crop Sci. 41, 1985-1987.

Swaddiwudhipong W., Limpatanachote P., Mahasakpan P., Krintratun S., Padungtod C. (2007) Cadmium-exposed population in Mae Sot District, Tak Province: 1 . Prevalence of high urinary cadmium levels in the adults, J. Med. Assoc. Thai 90, 143-148.

Tagwira F. (1993) Some chemical and physical factors that associated with micronutrient status and availability in Zimbabwean soils, Zimbabwean J. Agr. Res. 31, 1051-1059.

Takkar P.N., Walker C.D. (1993) The distribution and correction of zinc deficiency, in: Robson A.D. (Ed.), Zinc in Soils and Plants, Kluwer Academic Publishers, Dordrecht, The Netherlands, pp. 151-165.

Thung M. (1988) Phosphorus: A limiting nutrient in bean (Phaseolus vulgaris L.) production in Latin America and field screening for efficiency and response, in: Bassam N., Dambroth M.C., Loughman B.C. (Eds.), Genetic Aspects of Plant Mineral Nutrition, Kluwer Academic Publishers, Dordrecht, pp. 501-521.

Thongbai P., Hannam R.J., Graham R.D., Webb M.J. (1993) Interaction between zinc nutritional status of cereals and Rhizoctonia root rot severity. I. Field observation, Plant Soil 153, 207-214.
Tillman D. (1999) Global environmental impacts of agricultural expansion: the need for sustainable and efficient practices, Proc. Natl Acad. Sci. (USA) 96, 5995-6000.

Timsina J., Connor D.J. (2001) Productivity and management of ricewheat cropping systems: Isssues and challenges, Field Crop. Res. $69,93-132$.

Torun A., Gültekin I., Kalayci M., Yilmaz A., Eker S., Cakmak I. (2001) Effects of zinc fertilization on grain yield and shoot concentrations of zinc, boron, and phosphorus of 25 wheat cultivars grown on a zinc-deficient and boron-toxic soil, J. Plant Nutr. 24, 1817-1829.

UNICEF: Vitamin A Supplementation: A Decade of Progress (2007) The United Nations Children's Fund (UNICEF).

United Nations General Assembly (2000) United Nations Millennium Declaration, A/RES/55/2.

United Nations Administrative Committee on Coordination Subcommittee on Nutrition Situation (1992) Vol. 1. Global and Regional Results, World Health Organization, Geneva, Switzerland, pp. 1-80.

US Department of Health and Human Services. Healthy people 2000, Nutrition Today (1990) November/December, 29-30.

Verna T.S., Minhas R.S. (1987) Zinc and phosphorus interaction in a wheat-maize cropping system, Fert. Res. 13, 77-86.

Vijayaraghavan K. (2002) Control of micronutrient deficiencies in India: obstacles and strategies, Nutr. Rev. 60, S73-S76.

Walker D.W., Jenkins D.D. (1986) Influence of sweet potato plant residue on growth of sweet potato vine cuttings and cowpea plants, HortSci. $21,426-428$.

Walker D.W., Hubbell T.J., Sedberry J.E. (1989) Influence of decaying sweet potato crop residues on nutrient uptake of sweet potato plants, Agr. Ecosyst. Environ. 26, 45-52.

Wallace A., Mueller R.T. (1973) Effects of chelated and non-chelated cobalt and copper on yields and microelement composition of bush beans grown on calcareous soil in a glasshouse. Soil Sci. Soc. Am. Proc. 37, 904-908.

Wallace G.A., Wallace A. (1982) Micronutrient uptake by leaves from foliar sprays of EDTA chelated metals, in: Nelson S.D. (Ed.), Iron Nutrition and Interactions in Plants, Marcel Dekker, Basel, pp. 975978.

Webber M.D., Webber L.R. (1983) Micronutrients and heavy metals in livestock and poultry manures, in: Farm Animal Manures in the Canadian Environment. Publication No. NRCC 18976 of the Environmental Secretariat, Ottawa, Canada, p. 59.

Wei X., Hao M., Shao M., Gale W.J. (2006) Changes in soil properties and the availability of soil micronutrients after 18 years of cropping and fertilization, Soil Till. Res. 91, 120-130.

Welch R.M. (1998) Fashioning healthful agricultural systems, in: Combs G.F. Jr., Welch R.M. (Eds.), Creating Healthful Food Systems: Linking Agriculture to Human Needs Cornell International Institute for Food, Agriculture and Development, Cornell University, Ithaca, NY, pp. 7-13.

Welch RM. (1999) Importance of seed mineral nutrient reserves in crop growth and development, in: Rengel Z. (Ed.), Mineral Nutrition of Crops: Fundamental Mechanisms and Implications, Food Products Press, New York, pp. 205-226.

Welch R.M. (2002) The impact of mineral nutrients in food crops on global human health, Plant Soil 247, 83-90.

Welch R.M., Graham R.D. (1999) A new paradigm for world agriculture: meeting human needs - Productive, sustainable, nutritious, Field Crop. Res. 60, 1-10. 
Welch R.M., Graham R.D. (2000) A new paradigm for world agriculture: productive, sustainable, nutritious, healthful food systems, Food Nutr. Bull. 21, 361-366.

Welch R.M., Graham R.D. (2004) Breeding for micronutrients in staple food crops from a human nutrition perspective, J. Exp. Bot. 55, $353-364$.

Welch R.M., Allaway W.H., House W.A., Kubota J. (1991) Geographic distribution of trace element problems, in: Mortvedt J.J., Cox F.R., Shuman L.M., Welch R.M. (Eds.), Micronutrients in Agriculture 2nd ed., Soil Sci. Soc. Am., Madison, WI, pp. 31-57.

Welch R.M., Combs G.F. Jr., Duxbury J.M. (1997) Toward a "Greener" revolution, Issues Sci. Technol. 14, 50-58.

White P.J., Broadley M.R. (2005) Biofortifying crops with essential mineral elements, Trends Plant Sci. 10, 586-593.

Williams C.H., David D.J. (1976) Effects of pasture improvement with subterranean clover and superphosphate on the availability of trace metals to plant, Aust. J. Soil Res. 14, 85-93.

Williams P.N., Price A.H., Raab A., Hossain S.A., Feldmann J., Meharg A.A. (2005) Variation in arsenic speciation and concentration in paddy rice related to dietary exposure, Environ. Sci. Technol. 39, $5531-5540$

Woodbury P.B. (1992) Trace elements in municipal solid waste composts: A review of potential detrimental effects on plants, soil biota, and water quality, Biomass Bioenerg. 3, 239-259.

World Health Organization (1992) Second report on the world nutrition situation. Global and regional results, United Nations Administrative Committee on Coordination - Subcommittee on Nutrition, Geneva, Switzerland, 1, pp. 1-80.
World Health Organization (1996) Trace elements in human nutrition and health, Geneva, pp. 30-35, 90-91.

World Health Organization (1999) Malnutrition Worldwide. http: www.who.int/nut/malnutrition_worldwide.htm, World Health Organization, Geneva, pp. 1-13.

Yang X.E., Chen W.R., Feng Y. (2007) Improving human micronutrient nutrition through biofortification in the soil-plant system: China as a case study, Environ. Geochem. Hlth 29, 413-428.

Ye X., Al-Balil S., Kloli A., Zhang J., Lucca P., Beyer P., Potrykus I. (2000) Engineering the provitamine A (b-carotene) biosynthetic pathway into (carotenoid-free) rice endosperm, Science 287, 303305.

Yilmaz A., Ekiz H., Torun B. et al. (1997) Effects of different zinc application methods on grain yield and zinc concentrations in wheat grown on zinc-deficient calcareous soils in Central Anatolia, J. Plant Nutr. 20, 461-471.

Yilmaz A., Ekiz H., Gültekin I., et al. (1998) Effect of seed zinc content on grain yield and zinc concentration of wheat grown in zinc-deficient soils, J. Plant Nutr. 21, 2257-2264.

Yodkeaw M., De Datta S.K. (1989) Effects of organic matter and water regime on the kinetics of iron and manganese in two high $\mathrm{pH}$ rice soils, Soil Sci. Plant Nutr. 35, 323-335.

Zuo Y., Zhang F. (2008) Effect of peanut mixed cropping with gramineous species on micronutrient concentrations and iron chlorosis of peanut plants grown in a calcareous soil, Plant Soil 306, 23-36.

Zuo Y., Zhang F. (2009) Iron and zinc biofortification strategies in dicot plants by intercropping with gramineous species. A review, Agron. Sustain. Dev. 29, 63-71. 